\title{
Patterns and trends in internet of things (IoT) Research: Future applications in the construction industry
}

\begin{abstract}
Purpose: The Internet of Things (IoT) provides exciting opportunities for the construction industry to solve its time and resource constraints and frequent defaults. This study seeks to identify and rank the perceived importance level of principal research areas associated with the IoT and the construction industry by utilising a scientific mapping tool (i.e. VOS Viewer). Such knowledge would enable key drivers for successful adoption of the IoT and digitisation technologies to be outlined. An analysis of key drivers and research trends that facilitates the development of a roadmap for applying the IoT and digital technologies in the construction sector is therefore much needed.
\end{abstract}

Design/methodology/approach: An interpretivist philosophical lens was adopted to analyse published work as secondary data, where each publication represented a unit of analysis. A total of 417 peer-reviewed journal review articles covering the IoT within the construction domain were systematically reviewed using a mixed-methods approach, utilising qualitativescientometric analyses techniques.

Findings: The results reveal a field of study in a fledgling stage, with a limited number of experts operating somewhat in isolation and offering single point solutions instead of taking an integrated 'holistic' approach. Key publication outlets are identified and the main focus of research undertaken being in the technical areas of smart buildings, smart construction objects and environmental sustainability. The major effects of adopting the IoT within the construction industry were identified as high-speed reporting, complete process control, data explosion leading to deep data analytics, strict ethical and legal expectations. Key drivers of 
the IoT adoption were outlined as: interoperability; data privacy and security; flexible governance structures; and proper business planning and models.

Originality: The study is the first scientometric review of the existing body of knowledge in the context of application of the IoT in the construction industry. Findings expose knowledge gaps in contemporary research, specifically, a broader consideration of organisational adjustments needed to accommodate the IoT usage, economic analyses and impediments to wider acceptance.

Practical Implications: The study benefits researchers and industry practitioners alike. For researchers, the identified gaps reveal areas of high priority in future research. For construction companies, particularly small to medium-sized businesses, the study raises awareness of the latest developments and potential applicability of the IoT in the industry. For government agencies and policymakers, this study offers a point of reference in directing the adoption of the IoT smoothly in the construction sector and provides guidelines and standards for maximising the potential benefits.

KEYWORDS: Industry 4.0, Internet of Things, Sensors, Digitalisation, Construction, 5G, Scientometric analysis, Strategic roadmap

\section{INTRODUCTION}

Worldwide, the construction industry has been grossly underperforming losing around \$1.6 trillion annually due to low productivity rates (Sriram Changali et al., 2013). Researchers have calculated that around $57 \%$ of labour hours are spent on non-value added activities compared with $26 \%$ within the manufacturing sector (Langmade, 2017). In addition, traditional and at times, physically demanding methods of construction also contribute to the portrayal of a unglamorous and unattractive sector that hinders school leavers and graduates from taking up a vocation in the sector (Waters and McAlpine, 2016). These issues can be 
addressed through the use of innovative technologies ( $\mathrm{Li}$ and Liu, 2019) under the aegis of Industry 4.0 (Oesterreich and Teuteberg, 2016; Newman et al., 2020). Such technological solutions are more attractive to the tech-savvy generation $\mathrm{Z}$ youth (Turner, 2015) as they enter the employment market and can automate manual processes thus, improving productivity on and off site (Arashpour et al., 2017, Edwards et al., 2019). Therefore, there is an urgent need to inextricably link and embed innovative 'technology enabled' processes via the IoT in the construction industry to reduce uncertainties and streamline all activities in a systematic manner (Woodhead et al., 2018, Newman et al., 2020). Applied correctly, advanced technologies such as the IoT are indivisible to gaining organisational performance improvements that make the management of planning and monitoring easier (Xu et al., 2018, Berawi et al., 2019). They may also assist workers to efficiently perform their tasks with optimum productivity (Fernando et al., 2019).

Despite the significant and plethora of advantages offered by Industry 4.0 for enhancing the construction industry's performance (Bebelaar et al., 2018; Ghosh et al., 2020), a review of extant literature demonstrates conspicuous deficiencies with existing research undertaken; for example, there is a notable disconnect between academic endeavours and industry practice (Maskuriy et al., 2019). That is, whilst there has been a significant increase in the number of published studies on the IoT (cf. Carmona et al., 2019), there has hitherto been little attempt to bring these studies together as one cohesive whole and provide a broader picture of contemporary IoT developments (Sawhney et al., 2020). Previous review studies that sought to identify the nucleus and implications of Industry 4.0 research in the construction sector were predominantly subjective and qualitative (Oesterreich and Teuteberg, 2016, Maskuriy et al., 2019). Consequently, such work is susceptible to each individual researcher's subjective disposition and/or bias (Harden and Thomas, 2010, Hosseini et al., 2018a). Some conceptual studies are available too. These studies predominantly focus on narrows areas of integrating 
Industry 4.0 into the construction domain (Axelsson et al., 2019) or attempt to showcase the need or the nature of the change needed (Woodhead et al., 2018, Tang et al., 2019, Alaloul et al., 2020).

While these formative works invariably raise the profile of Industry 4.0 research (and were invaluable in terms of setting the broader scope and contextualisation of the phenomena), no previous study has provided an exhaustive comprehension of major research streams investigated, geographical distribution of active researchers in the field or targeted scientific outlets. Against this contextual backdrop, this research aims to address these observed deficiencies by providing the first systematic literature analysis on construction industry applications of the IoT within the broader domain of Industry 4.0. Specifically, the study widens the frame of reference and adopts a structured, quantitative methodology to generate a comprehensive, objective portrait of the existing state of research knowledge. Accompanying objectives are to: 1) implement a science mapping technique (cf. Chamberlain et al., 2019) to outline research trends and network clustering as the basis for the development of a strategic roadmap. This roadmap identifies core emergent themes and trends in IoT research and importantly, implications for broader research; 2) identify and rank key drivers for successful adoption of the IoT and digitisation technologies in the construction sector so that the finer nuances between them can be determined and thus, generate greater insight; and 3) identify weakness and deficiencies within current research, and present remedial solutions and recommended priority themes for future studies. These recommendations encapsulate a research agenda that cites strategic goals together with relevant objectives and measures for attaining the same. The research findings will provoke renewed polemic scholarly debate, augment problem diagnosis and close this observed knowledge gap. Cumulatively, the proposed research provides an invaluable guideline for government policymakers to adopt this emerging technology and optimally maximise its benefits. Consequently, the findings 
will signpost Industry 4.0 researchers and government policymakers to direct their efforts towards reasoned future research strategies and formulation of 'impactful' research topics.

\section{BACKGROUND}

With a GDP of around $\$ 17,140$ billion as of 2017 , the global construction market is expected to grow to $\$ 24,334$ billion in 2021 at an impressive compound annual growth rate (Reportlinker, 2019). The sector is expected to contribute to around 15\% of the world GDP by 2030 (Craveiro et al., 2019). The Organisation for Economic Co-operation and Development (OECD) estimates that the global construction workforce accounts for $7 \%$ of the global population (Nieuwenkamp, 2016). Being a labour-intensive industry, it provides employment with a low investment thus, contributing widely towards reducing the unemployment rate in many low income nations (Arvis et al., 2016). Furthermore, the inextricably linked 'push' and 'pull' multiplier associated with construction activities effects other inter-connected economic sectors within the supply chain such as quarrying and manufacturing (Chiang et al., 2015). In the construction industry, the process of innovation and the adoption of change is inherently slower when compared to technologically advanced sectors such as manufacturing, aviation and electronics (Hosseini et al., 2015, Loosemore, 2015; Pärn and Edwards, 2017). Slaughter's (2000, p. 2) definition of innovation is widely recognised by academics and industry personnel within the construction industry viz:

"Innovation is the actual use of nontrivial change and improvement in a process, product, or system that is novel to the institution developing the change."

It is with a view to addressing these issues through innovation that researchers have endeavoured to use product technologies and process improvements to augment competitiveness in the construction industry (Fewings and Henjewele, 2019). However, since material costs typically dominate construction projects (Sutrisna et al., 2019), there is an 
inclination to prioritise 'product' over 'process' innovations. Under the 'product' innovation umbrella, numerous techniques associated with Industry 4.0 have been used to provide innovative solutions to solve construction problems (Shen et al., 2015). These techniques include: Building Information Modelling (BIM) (Eastman et al., 2018, Bensalah et al., 2019, Al-Saeed et al., 2020); smart construction objects (Niu et al., 2015); ubiquitous technologies (Melià-Seguí and Vilajosana, 2019); augmented reality (Bademosi et al., 2019); and blockchain (Pärn and Edwards, 2019, Li et al., 2019, Dewan and Singh, 2020). Coalescence of these technologies enables changes to the construction industry's antiquated modus operandi (Golizadeh et al., 2018).

\section{The concept of IoT}

Whilst, there is no universal official definition for the IoT (Čolaković and Hadžialić, 2018), the concept dates back to 1982 when a modified coke machine was connected to the internet to manage drinks inventory (Farooq et al., 2015). The term ' $\mathrm{IoT}$ ' is nevertheless a concept first coined in 1999 by Kevin Ashton in the context of supply chain management (Ashton, 2009, Gamil et al., 2020, Sawhney et al., 2020). It is defined as an interconnected network of physical objects with sensing, actuating and communication capabilities that enable a unified framework for data syntheses and processing, through seamless access to domain-specific software and services (Gubbi et al., 2013, Perera et al., 2014). Perera et al. (2014) state that the IoT is not a revolutionary novel technological step but rather the next phase in the evolution of the internet itself. It represents a coalescence of complementary technologies and standards - with capabilities that bridge the gap between the real and the virtual worlds (Balaji and Roy, 2017, Čolaković and Hadžialić, 2018).

Various IoT enabling technologies are categorised into four domains or layers: application (application layer); middleware (perception layer); networking (network layer); and object 
(physical layer). These make up the four broad layers of the IoT umbrella (cf. Kumar et al., 2016 and Čolaković and Hadžialić, 2018).

\section{Added value for the Built Environment}

A plethora of potential benefits are associated with using the IoT in the built environment because its applications cover all the activities performed by persons, organisations and the wider community (Kaklauskas and Gudauskas, 2016). The promise of the IoT lies in its capability in enabling physical objects to automatically record, generate and act upon data over the internet (Ashton, 2009) - attrbiutes essential to deciion support and wider management. At present, these tasks are primarily performed manually and are prone to the problems of limited resources and accuracy (Gamil et al., 2020). The growing application of the IoT has added significant value in many sectors such as the automotive, mining, defence, agriculture and manufacturing; all of which are far advanced when compared to the comparatively out-dated construction sector (Mourtzis et al., 2016). The use of the IoT results in real-time data collection and sharing among key resources of any industry including machines, personnel, materials and tasks (Zhong et al., 2017). This intrinsic capability enables the IoT to develop intelligent applications in a wide range of industries. Some in the built environment domain include smart healthcare facilities; smart transportation and traffic systems; fleet tracking solutions; control of logistics chain; smart cities; industrial automation; collision avoidance systems in cars; energy efficiency; waste management; smart buildings/homes/offices; and environment monitoring, among others (Souri et al., Atzori et al., 2010, Kaklauskas and Gudauskas, 2016, Čolaković and Hadžialić, 2018). Integrating the IoT into the built environment can improve the quality of human interaction experience within the built environment, allow real-time monitoring, enable smart built environment and reduce energy consumption (Farooq et al., 2015, Haase et al., 2016). 
Potential applications of the IoT for the built environment are myriad (Kaklauskas and Gudauskas, 2016), a description of which follows.

\section{The construction sector and IoT}

The IoT is increasingly pervading the construction industry, where researchers attempt to harness its various potential benefits (Veras et al., 2018, Woodhead et al., 2018). It is predicted that the IoT will have a monetary impact of saving $22-29 \%$ of the total costs, equating to \$75-96 billion in annual benefits in the construction context (ACS, 2018). The IoT will ensure high speed of reporting, reducing the cost of communication but also potentially removing human error or omissions being introduced. It will also enable better process control and optimisation through advanced algorithms and artificial intelligence that can help interpret the data not simply analyse it (Al-Ali et al., 2017). The massive amount of data collected would enhance monitoring and analysis even at the micro-level; leading to better accountability, transparency and enhanced monitoring (Sun, 2012, Attia et al., 2018, Bibri, 2018).

Implementing the IoT within the construction sector has the potential to bring about new economic opportunities (for example, computer programmers and analysts to work more integrated within a project team) and contribute to a larger data environment for future big data-driven insight (Bilal et al., 2016). Given this new technology, unprecedented volumes of data must be processed and synthesised into actionable insight (Bibri, 2018, Louis and Dunston, 2018) - particualrly for problems that doggedly persist in the construction industry such as compensation claims, disputes and low productivity. Moreover, the IoT has considerable opportunities and use cases in the built environment and broader Architecture, Engineering, Construction, and Operations (AECO) industry (Attia et al., 2018, Bibri, 2018). Examples could include facilities management during the in-use phase of a building's life cycle or demolition waste management at the end of the building's life cycle. 


\section{RESEARCH METHODS}

An interpretavist philosophical design is implemented for this research using published literature as the unit of analysis (Roberts et al., 2019); where interpretavism allows for the researcher's individual nuance and variability in their interaction with (in this case literature) to interpret and/or comprehend new knowledge, perspectives and generate wisdom (Dixon et al., 2020). Consequently, this philosophical stance is broadly categorised as being an inductive paradigm (Al-Saeed et al., 2018). Interpretavism has been widely used within construction management and civil engineering research, for example to: investigate the Grenfell Tower disaster (Mohamed et al., 2019); explore the barriers to BIM implementation in China's prefabricated construction sector (Tan et al., 2019); and analyse the use of artificial intelligence research in the construction industry (Darko et al., 2020). The operational application of this philosophy was achieved through a cross sectional 'mixed-methods systematic review' - the benefits of which have been adequately noted by Guetterman et al. (2019). The hallmark of mixed methods is the integration of quantitative and qualitative data to generate meta-inferences beyond what either approach could have done alone (Malina et al., 2011). Mixed methods provide an objective lens through enhanced quantitative and qualitative means to overcome potential bias which easily creeps into manual systematic reviews (Harden and Thomas, 2010, Jin et al., 2018, Jin et al., 2019). Adhering to the above approach, the research design adopted is a three-pronged review process viz: 1) data acquisition; 2) scientometric analysis; and 3) qualitative analysis - refer to Figure 1.

\section{$<$ Insert Figure 1 about here $>$}

\section{Data acquisition}

Data for a mixed methods systematic review could be sourced from several databases, such as the Web of Science, PubMed, Google Scholar or Scopus. Of these, Scopus was selected 
since it has a wider range of coverage, faster indexing process and lists more recent publications (Hosseini et al., 2018a, Hosseini et al., 2018b). The search query was selected to cover all known keywords in this field comprised of TITLE-ABS-KEY ("internet of things" OR "industrial internet" OR "IoT" OR "sensors " OR "cyber physical systems" OR "wireless sensor network" OR "WSN") AND (LIMIT-TO (SRCTYPE, "j" )) AND (LIMITTO (DOCTYPE, "ar")) AND (LIMIT-TO (EXACTSRCTITLE, "Automation In Construction") OR LIMIT-TO (EXACTSRCTITLE, "Journal of Construction Engineering and Management") OR LIMIT-TO (EXACTSRCTITLE, "Journal of Computing in Civil Engineering") OR LIMIT-TO (EXACTSRCTITLE, "Construction Management and Economics") OR LIMIT-TO (EXACTSRCTITLE, "Engineering Construction and Architectural Management") OR LIMIT-TO (EXACTSRCTITLE, "Construction Innovation: Information, Process, Management") OR LIMIT-TO (EXACTSRCTITLE, "Canadian Journal of Civil Engineering") OR LIMIT-TO (EXACTSRCTITLE, "International Journal of Construction Education and Research") OR LIMIT-TO (EXACTSRCTITLE, "Building Research and Information") OR LIMIT-TO (EXACTSRCTITLE, "Architectural Engineering and Design Management") OR EXCLUDE (EXACTSRCTITLE, "t LIMIT-TO EXACTSRCTITLE") OR EXCLUDE ( EXACTSRCTITLE , "t LIMIT-TO LANGUAGE" )). As evident in the search query, only the top 10 construction management Q1 rated journals were selected (cf. Wing, 1997, Hosseini et al., 2015). Journals targeted included: Construction Management and Economics; Journal of Management in Engineering; Engineering, Construction and Architectural Management; Automation in Construction; International Journal of Project Management; and Building Research and Information. In addition, other relevant journals containing highly cited papers, including Building and Environment, Canadian Journal of Civil Engineering and Journal of Computing in Civil Engineering, were added to the search list, in accordance to the list deployed by Yi and Chan 
(2014). Five other journals were added to the review list, including: Construction Innovation: Information, Process, Management; Architectural Engineering and Design Management; International Journal of Construction Management; International Journal of Construction Education and Research; and Australasian Journal of Construction Economics and Building. These additional journals were selected from the array of high-ranking construction management journals introduced by the list of Excellence in Research for Australia, following Hosseini et al. (2015). However, some of the selected journals did not have relevant articles pertaining to the search query and were automatically omitted which left seven high quality relevant journals selected for review - refer to Figure 2.

\section{<Insert Figure 2 about here>}

No time limitation was set on the search criteria to ensure a comprehensive coverage of existing literature was obtained (Hosseini et al., 2018b). The document type was refined to filter only articles published in journals - the rationale being that for science mapping purposes, journal articles represent the most influential research studies (Santos et al., 2017). Conference papers in the construction management and civil engineering discipline (unlike those published in IT) are published in large numbers and are of lesser scientific quality hence, little is gained by including them, given the extra level of complexity added to the analyses (Butler and Visser, 2006). Keywords were searched on abstract, title and keywords. The search result provided 417 journal articles related to the IoT in the construction industry up to $20^{\text {th }}$ February 2020. The final scientometric analysis was performed on these 417 journal articles in English. The reason for selecting review papers was two-fold: first, a manageable sample-size for comprehensive scientometric and qualitative analysis could be obtained; and second, a review of existing review papers could cover an exhaustive body of literature but also reflect upon the directions of review studies in this field. This approach 
provides a suitably large sample size for using scientometric analysis (cf. Mahon and Joyce, 2015).

\section{Scientometric analysis}

Mixed methods systematic reviews draw upon computer aided quantified techniques that analyse the available body of knowledge in an area under investigation (Oraee et al., 2017). Of these, scientometric analysis of literature is widely used across many disciplines and informs the present study. Scholarly data on the IoT in the construction industry is mapped and visually represented in accordance with similar research work in construction safety (Jin et al., 2019) and BIM (He et al., 2017).

A plethora of software packages are available for scientometric analysis, each with unique features and/or limitations; these programs include: VOSviewer, BibExcel, CiteSpace, CoPalRed, Sci2, VantagePoint and Gephi (Cobo et al., 2011).

Visualisation of Similarities, better known as simply VOSviewer (www.vosviewer.com) was utilised because it is a freely available tool that offers all the basic functionality needed for visualising scientometric networks. Moreover, the tool is easy to use, where results are readily comprehensible with minimum technical skills. Because of these features, VOS Viewer has witnessed an increased rate of adoption by construction researchers (Jin et al., 2018, Jin et al., 2019).

\section{Qualitative analysis}

Qualitative analysis conducted followed the steps proposed by Harden and Thomas (2010), Roberts et al. (2018) and Jin et al. (2019). This step entailed comparing the concepts and themes outlined in the content of selected studies via term coding, in two cycles to ensure interpretive convergence following the lessons by Bazeley (2013). The intention was to provide a comprehensive qualitative synthesis and in-depth evaluation of the content of 
selected studies on the IoT in the construction context. Particular attention was paid to prevailing gaps in knowledge, limitations of the selected studies but also formulating future recommended research work across these studies.

\section{RETRIEVED DATA RESULTS}

Figure 2 illustrates the number of publications devoted to the IoT applications in the context of construction projects (1988 to 2020). The first study in 1983, published in Architectural Science Review, with the title "Computer-aided architectural design—Past, Present and Future" (Gero, 1983). The paper (ibid) discussed the development of computer-aided drafting and designing over the period 1960 to 1980 from the planning of hospitals (Souder and Clark, 1963) to spatial planning techniques (Levin, 1964) to increasing adoption of computer software in architecture due to low hardware costs. Interestingly, the first computer in Sydney University was priced around $\$ 500,000$ in 1953 , yet about $\$ 5,000$ in 1983 (AUS dollars) (Gero, 1983). This early period of research in this field comprised of one or two articles annually. The trend continued till the millennium. Yet the year 2000 proved to be a milestone in the field of the IoT research in the construction industry with 18 articles published. Post 2015 witnessed an exponential increase in the number of articles related to this field with 52 and 47 articles published in 2018 and 2019 respectively as research momentum gathered pace.

Major research outlets facilitating research in this field were led by Automation in Construction with a frequency (f) of 222 research outputs, followed by Journal of Computing in Civil Engineering ( $f=85$ ) and Canadian Journal of Civil Engineering ( $f=63$ ) (see Figure $3)$.

\section{<Insert Figure 3 about here>}


An analysis of major subject areas of research outputs in this field reveals the multidisciplinary nature of this field. While it is evident that most articles fall squarely under the category of engineering journals $(f=417)$, some are categorised under the fields of computer science ( $f=85$ or $20.38 \%$ ), environmental science ( $f=63$ or $15.10 \%$ ) and business, management and accounting ( $\mathrm{f}=47$ or $11.27 \%$ ). This shows the evolving multidisciplinary nature of this field and/or the increasingly transient nature of construction academics who readily compete in journals outside of their own traditional discipline (refer to Figure 4).

\section{<Insert Figure 4 about here>}

An analysis into the leading institutions in this field of enquiry showed Georgia Institute of Technology and Hong Kong Polytechnic University leading the list with $f=17$ articles, followed by University of Michigan, Ann Arbor ( $\mathrm{f}=16)$ and University of Texas, Austin ( $\mathrm{f}=$ 11) (refer to Figure 5)

\section{$<$ Insert Figure 5 about here $>$}

An analysis into the major funding agencies with high research outputs shows the National Science Foundation leading with $\mathrm{f}=28$ articles, followed by National Natural Science Foundation of China ( $f=17)$ and Natural Sciences and Engineering Research Council of Canada $(f=10)($ refer to Figure 6$)$

\section{$<$ Insert Figure 6 about here>}

\section{DISCUSSIONS AND KEY OBSERVATIONS}

The minimum number of occurrences for a resultant term to qualify for visualisation in the text map produced by VOS Viewer was set at 20. This resulted in 105 terms meeting the threshold out of an overall term database comprising of 10,932 terms. From these 105 terms, only the top $60 \%$ articles with highest relevance score are selected resulting in 63 being 
selected. Based on manual observation, certain terms were omitted since they were deemed to provide little context for visualising emergent themes in this scientific review. The terms omitted were: comparison, construction, construction industry, feature, implementation, industry, internet, IoT, measurement, methodology, practice, problem, project, requirement, technique, technology, term and thing. From Figure 7, the terms collated are clustered around four main thematic groups that were arbitrarily entitled: cluster one - structural health monitoring; cluster two - construction safety; cluster three - optimisation and simulation; and cluster four - image processing. A collection of all the terms (45) belonging to each research cluster is provided in Appendix 1.

\section{<Insert Figure 7 about here>}

\section{Cluster one - structural health monitoring}

Structural health monitoring represented one of the major clusters observed in Figure 7 . With a cluster group comprising of 14 items (see Appendix 1), keywords like addition, BIM, bridge, building, case study, component, damage, effect, sensor, strain, strategy, structure, type and user were clustered around this theme. Research was focussed on assessing the application of the IoT tools and techniques to provide real time information regarding the structural health of buildings and their components through sensor-based techniques. It can be observed that sensor and structural health monitoring techniques received the highest citations (denoted by larger circles otherwise known as 'nodes') in addition to having an older average citation year. The scale 2011-2015 signifies the average citation year with a change in colour from deep blue signifying older research themes to pale yellow signifying the latest themes. This cluster is identified to be well established in literature and has received significant attention from researchers.

\section{Cluster two - construction safety}


Enhancing worker safety was an emergent application of the IoT concepts. Themes like accident, challenge, construction site, construction worker, device, productivity, real-time, RFID [radio frequency identification tags], safety, task, work and worker were some of the primary areas of focus for researchers. It was encouraging to observe a strong research focus on worker safety given that this theme is sometimes neglected especially in developing nations (Gammon, 2020). It was also observed that the themes under this cluster ranged in average publication year from 2014-2015 which suggests that this cluster continues to receive academic attention.

\section{Cluster three - optimisation and simulation}

Optimisation and simulation studies are prominent avenues of research, particularly for facilitating the easy transfer of an emergent computing technology such as the IoT (Brundu et al., 2016). Optimisation of the IoT technologies to meet the needs of the sector becomes a major criterion for translation of theory into practice. Under this backdrop, research into themes like accuracy, algorithm, error, experiment, experimental result, GPS, object, position, robot and simulation have been given primary importance. These themes ranged in average publication year from 2011-2012 which suggests that the cluster identified is well established in the literature and has received significant attention from researchers.

\section{Cluster four - image processing}

Image processing was one of the important clusters in the IoT research. Intelligent image processing algorithms of construction materials for quality control and inventory management is a primary focus of researchers (Anding et al., 2013). Themes like camera, equipment, excavator, image, operator, part, time, vehicle and vision have been the focus of research conducted. 
The next stage comprises of analysing the author collaboration networks and identifying prominent researchers with most impact in this field. While Figure 5 provides an overview of authors with the most publications and Figure 8 provides a summary of the authors' collaborative networks with the most citations; where a minimum number of five documents was kept as a qualifying criterion. Out of 1,111 authors, only 21 meet the threshold. Three major author collaborative clusters are observed. Additionally, Figure 9 represents organisations with a major impact in this field. A minimum number of two documents was set as qualifying criteria. Appendix 2 comprises the major institutional collaborative clusters. Lastly, an enquiry into the collaborative networks of countries is undertaken to visualise the major collaborations and leading nations along this field of enquiry. The minimum number of documents was set as five which resulted in 17 countries qualifying out of a total of 47 countries. The country collaboration network map is provided in Figure 10.

\section{<Insert Figures 8, 9 and 10 about here>}

\section{INTERNET OF THINGS IN THE CONSTRUCTION SECTOR - A NEED FOR FUTURE APPLICATIONS}

Evidence shows that the IoT has promising construction industry applications (Mourtzis et al., 2016, Tang et al., 2019), enabling the capturing, recording, processing and synthesis of unprecedented volumes of data, into actionable insight (Kobusińska et al., 2018). The implementation of the IoT therefore, has the potential to bring about new economic opportunities and contributions to a larger data environment for future big data-driven insight (Bilal et al., 2016, Louis and Dunston, 2018). Integration of the IoT with Building Information Modelling (BIM) to create digital twins presents a powerful paradigm for applications with the potential for improving construction and operational efficiencies (Heiskanen, 2017, Khajavi et al., 2019, Tang et al., 2019). Moreover, the IoT is deemed to be 
an enabler for cyber-physical construction, colloquially termed as Construction 4.0 (Gamil et al., 2020, Sawhney et al., 2020).

The IoT provides exciting opportunities for practitioners to improve the industry's image and be at the forefront of utilising advanced technologies to solve its time and resource constraints. Construction operations are typically spread across large areas and require remote collaboration between multiple contrasting departments and resources that create the need for ubiquitous, rapid and automated decision-making on the worksite (Louis and Dunston, 2018). The IoT utilises systems such as sensors and connected devices to monitor real-time parameters and harness the information gleaned through techniques like big data analytics and data mining to provide visually informative end-results (Riaz et al., 2006; 2017). For the construction industry to address the modern technological challenges in this Industry 4.0 age, it must adapt and transform itself from its traditional primitive methods to digitalised automated systems which will act as a major step forward towards improving its productivity, efficiency, environmental sustainability but also lead to dynamic planning and management (Dallasega, 2018).

It is predicted that the IoT will have a financially beneficial and significant impact upon the sector by: ensuring high speed of reporting to reduce the costs of communication (Ramasundara et al., 2018); and providing better process control and optimisation (Madakam and Uchiya, 2019). The huge amount of big data collected will improve monitoring and analysis even at the micro-level to provide better accountability and transparency as well as highlight the key performance indicators (KPIs) and their adequate monitoring. Cutting edge technologies that rely upon the IoT and the vast computational power of cloud-based servers will change the modus operandi of construction processes and procedures. Key technologies that are set the transform the industry include: bricklaying robots (FastBrick Robotics), automated OH \& S reporting (SmartSite), asset management (AutoDesk Fusion Connect), 
drone technology for aerial survey and monitoring and embedded technology in building components providing intelligent structural elements (Smart Products). These technologies will rely on the IoT and the massive computational power of network sensors to monitor and control these operations (Edwards et al., 2017).

\section{RESEARCH AGENDA}

Many new fertile areas of potential research related to the IoT in the construction sector require further exploration. Prime candidate areas for future research regarding the IoT technologies include:

- Disrupter to existing construction practices: the introduction of the IoT techniques in the construction industry represents a disruption to current work practices and many questions has arisen. These include: How the IoT is to be introduced and established within construction firms?; How is the transition away from current practices, along with the staff currently employed to be effected?; and How are new IoT-based practices to be integrated into existing, traditional, work practices? Beyond this is the broader issue of ensuring that the IoT usage is accepted within organisations and used optimally with limited resistance. Here, further organisational change management or risk management research is required.

- Skill development and changing job roles: While various training programs are available, these are experienced based and not founded upon substantive evidencebased understanding of the specific demands of the IoT-based operations. Moreover, knowledge management systems lack formal implementation, resulting in knowledge loss when moving from one project to the next, or when staff move on. Additionally, there would be a need for redefining of traditional job roles and redundancy of several existing ones which may prove to be an insuperable barrier for easy adoption of the IoT-based technologies. 
- Economics of IoT: the cost of deploying the IoT within organisations also raises questions relating to whether the IoT-based methods are cost effective and/or suitable for small and medium enterprises (SMEs). Initially, the investment into new technologies is financially front-loaded, , and even less efficient than existing technologies, though over time such financial investments will outperform the older systems they replace and over time, their cost benefits become more apparent. There is the internal learning effect consideration, as well as the industry cost-curve consideration (Papageorgiou and Demetriou, 2019). Even so, costing of the IoT-based techniques, the expected longer-term financial benefits, returns on investment (ROIs) and payback periods, remain untested. Moreover, the IoT-based techniques will need to be extensive, if not complete, once introduced, in order to justify the economics. But supplanting existing practices will also have a knock-on effect on other aspects of the construction enterprise, with further cost implications. Emergent questions here oscillate around determining the extent of disruption to existing practices brought on by the IoT's introduction, and the associated costs - both are yet to be adequately reconciled. Determining the economic value of the IoT-based methods, both at a firm level and at the industry level requires future research. Moreover, over time, the price and performance of the IoT-based techniques will continually improve. Delaying adoption will enhance value but there will also be marketplace opportunity costs in doing so. Optimisation of timing for the adoption of the IoT innovation in the construction industry is a further area of research interest.

- Interoperability of IoT practices within broader construction operations: the interface between existing practices that support the IoT-based operations, as well as receive the IoT-based output, can be expected to require adjustment of fit (Čolaković and Hadžialić, 2018, Dave et al., 2018). What the issues are, how they should be resolved, 
and how systems can be integrated to overcome interoperability issues all require further investigation.

- Data privacy, regulation and management: the huge amount of data generated and collected through the use of the IoT-based technologies necessitates the development of robust data management systems which ensure security and privacy of data generated and collected. Additionally, legislation for proper handling and management of data necessitates research in this avenue. Cyber security is a major international issue that impacts upon all sectors or industry and commerce as well as the general public (Caneppele and Aebi, 2019). Although blockchain, as a solution, has received some academic attention within the construction and civil engineering academic community, most prominent developments are being made in computers sciences (Dwivedi et al., 2019). This suggests that construction academics will need to collaborate more with other disciplines moving forwards vis-à-vis continue with isolated collaborative ventures within their own research community of practice.

- Scope of applicability: currently the applicability of the IoT-based methods is primarily focused on structural health monitoring, worker safety, optimisation, simulation and image smart image processing for material or asset management. Nevertheless, their evolution may extend to offering wholly new functions particularly for example, in materials supply chain logistics to ensure the timely manufacture and delivery of materials on site. Other applications and opportunities are likely to be numerous.

- Enhancement of current capabilities: at one level, current IoT research remains largely technical, exploring functionality and operability within its initial orbit of identified usages. Improving performance within these current ambits of operations is one obvious area of future research. A further area would be to explore potential for 
extending performance yet again, into fields such as remote robotics to resolve health, safety and welfare issues around lone workers. Lone workers are particularly problematic in the construction and civil engineering sector because should an accident/incident occur, then it is likely that this event may well go unnoticed for extended time periods.

- Change in managerial landscape: the IoT-based techniques would bring about a significant change in the managerial landscape of construction firms. Instead of following hierarchical organisation systems, a more team-based approach with a flatter organisation order should take place. Envisaged changes could include site administration, occupational health and safety $(\mathrm{OH} \& \mathrm{~S})$ monitoring, manpower management, project management. Further research is warranted across the change management of the managerial landscape within organisations who have adopted the IoT-based digital platforms. Although such adoption is intended to improve productivity and efficiency, changes in traditional management styles are also required to implement these digital platforms and at present, these changes are yet to be defined or delineated.

- Technology transfer: currently, adoption of the IoT-based methods in construction are largely serendipitous. A more rigorous investigation of transference opportunities and adaptation of the IoT-based techniques from other more technologically advanced sectors such as manufacturing and mining into construction is needed. Lessons learnt from these sectors could yield significant financial returns particularly, where trial and errors lessons in these other sectors are shared with construction and civil engineering practitioners.

\section{CONCLUSION}


The IoT constitutes one of the emerging Industry 4.0 tools available to the construction industry and its long-term impact is set to be extensive. Research in the area is at an embryonic stage of development but growing rapidly. The subject of the inquiry undertaken was to examine what is currently being studied, the integrity of that research and importantly, what areas are being neglected. Limited, selective and/or subjective research was apparent and so this current study addresses this by applying a strong, comprehensive, mixed-methods quantitative scientometric approach to present the first systematic study of the IoT in the construction industry literature. Key highlights are:

- A highly narrow research agenda is apparent that emphasises the applicability of the IoT in remote structural health monitoring, construction safety, optimisation and simulation and image processing.

- Research conducted is undertaken by only a few key researchers operating largely in isolation and without overt institutional level collaboration. This outcome may be expected, since the introduction of new technologies will demand in the first instance, research that tests, validates and improves the performance of that technology.

- Glaring deficiencies that can be expected to critically impact the greater inclusion of the IoT technologies across an increasing number of firms and the industry at large, as the scopes of operation continue to widen.

- Identification of deficiencies within the prevailing body of knowledge developed so far, along with confirmation of the isolated nature of researchers working on the IoT that are the value of this study.

- Directions for next steps needed, offering a future agenda to take the IoT research within the construction industry forward. Specifically, future work is warranted into how firms and industry as well as individuals and professions, can best respond, accommodate and adapt to the disruptive impact this ground-breaking technology. 
Moreover, measurement is required to determine how this technological upstart will change or evolve existing construction practices.

- Requirements to seek additional understanding of the various economic dimensions of the IoT applications, together with explorations of the legal environment in which they will operate and the legal implications of usage.

Despite the various contributions of this present study, the findings are to be considered in light of the following limitations.

- First, the findings bring with them the limitations of the utilised dataset, considering that the dataset only reflects those studies indexed prior to February 2020.

- Second, the study may also be restricted by the inherent limitations of Scopus in indexing some scholarly outlets. This points to the necessity of conducting similar studies in the form of longitudinal (vis-à-vis cross-sectional) assessments of the literature to reflect the trends of research on the topic.

- Third and finally, the study is predominantly an exploration of 'what' questions are found in the literature, rather than 'why' and 'how.' While several problems within the IoT domain are identified, investigating the sources of those problems along with their remedial solutions are areas to be addressed by future research.

\section{REFERENCES}

Al-Ali, A. R.Zualkernan, I. A.Rashid, M.Gupta, R. and Alikarar, M. (2017), “A smart home energy management system using IoT and big data analytics approach". IEEE Transactions on Consumer Electronics, Vol. 63 No. 4. pp. 426-434. 10.1109/TCE.2017.015014

Al-Saeed, Y., Pärn, E.A., Edwards, D.J. and Scaysbrook, S. (2019), "A conceptual framework for utilising bim digital objects (bdo) in manufacturing design and production: a case study", Journal of Engineering Design and Technology. Vol. 17 No. 5, pp. 960-984 DOI: https://doi.org/10.1108/JEDT-03-2019-0065\#

Al-Saeed, Y.Edwards, D. J. and Scaysbrook, S. (2020), "Automating construction manufacturing procedures using BIM digital objects (BDOs)". Construction Innovation. Vol. ahead-of-print No. ahead-of-print. DOI: https://doi.org/10.1108/CI-12-2019-0141 
Alaloul, W. S.Liew, M. S.Zawawi, N. A. W. A. and Kennedy, I. B. (2020), "Industrial Revolution 4.0 in the construction industry: Challenges and opportunities for stakeholders". Ain Shams Engineering Journal, Vol. 11 No. 1. pp. 225-230. https://doi.org/10.1016/j.asej.2019.08.010

Anding, K.Garten, D. and Linß, E. (2013), "Application of intelligent image processing in the construction material industry". ACTA IMEKO, Vol. 2 No. 1. pp. 61-73. DOI: https://doi.org/10.21014/acta_imeko.v2i1.100

Arashpour, M.Bai, Y.Aranda-mena, G.Bab-Hadiashar, A.Hosseini, R. and Kalutara, P. (2017), "Optimizing decisions in advanced manufacturing of prefabricated products: Theorizing supply chain configurations in off-site construction". Automation in Construction, Vol. 84. pp. 146-153. https://doi.org/10.1016/j.autcon.2017.08.032

Arvis, J.-F.Saslavsky, D.Ojala, L.Shepherd, B.Busch, C.Raj, A. and Naula, T. 2016. Connecting to Compete 2016: Trade Logistics in the Global Economy--The Logistics Performance Index and Its Indicators, World Bank. Available via: https://www.worldbank.org/en/news/feature/2016/06/28/connecting-to-compete-2016-tradelogistics-in-the-global-economy [Accessed: 23 ${ }^{\text {rd }}$ April, 2020].

Ashton, K. (2009), “That 'internet of things' thing". RFID journal, Vol. 22 No. 7. pp. 97-114.

Attia, M.Haidar, N.Senouci, S. M. and Aglzim, E. Towards an efficient energy management to reduce CO2 emissions and billing cost in smart buildings. 2018 15th IEEE Annual Consumer Communications \& Networking Conference (CCNC), 12-15 Jan. 2018 2018. 1-6. 10.1109/CCNC.2018.8319226

Atzori, L.Iera, A. and Morabito, G. (2010), "The Internet of Things: A survey". Computer Networks, Vol. 54 No. 15. pp. 2787-2805. https://doi.org/10.1016/j.comnet.2010.05.010

Axelsson, J.Fröberg, J. and Eriksson, P. (2019), "Architecting systems-of-systems and their constituents: A case study applying Industry 4.0 in the construction domain". Systems Engineering, Vol. 22 No. 6. pp. 455-470. 10.1002/sys.21516

Bademosi, F.Blinn, N. and Issa, R. R. (2019), "Use of augmented reality technology to enhance comprehension of construction assemblies". Journal of Information Technology in Construction, Vol. 24 No. 4. pp. 58-79. DOI: http://www.itcon.org/2019/4

Balaji, M. S. and Roy, S. K. (2017), "Value co-creation with Internet of things technology in the retail industry". Journal of Marketing Management, Vol. 33 No. 1-2. pp. 7-31. 10.1080/0267257X.2016.1217914

Bazeley, P. 2013. Qualitative data analysis : practical strategies, SAGE, Thousand Oaks, Calif.

Bebelaar, N.Braggaar, R. C.Kleijwegt, C. M.Meulmeester, R. W. E.Michailidou, G.Salheb, N.van der Spek, S.Vaissier, N. and Verbree, E. (2018), "Monitoring urban environmental phenomena through a wireless distributed sensor network". Smart and Sustainable Built Environment.

Bensalah, M.Elouadi, A. and Mharzi, H. (2019), "Overview: the opportunity of BIM in railway". Smart and Sustainable Built Environment.

Berawi, M. A.Sunardi, A. and Ichsan, M. (2019), "Chief-Screen 1.0 as the Internet of Things Platform in Project Monitoring \& Controlling to Improve Project Schedule Performance". Procedia Computer Science, Vol. 161. pp. 1249-1257. https://doi.org/10.1016/j.procs.2019.11.239

Bibri, S. E. (2018), "The IoT for smart sustainable cities of the future: An analytical framework for sensor-based big data applications for environmental sustainability". Sustainable Cities and Society, Vol. 38. pp. 230-253. https://doi.org/10.1016/j.scs.2017.12.034

Bilal, M.Oyedele, L. O.Qadir, J.Munir, K.Ajayi, S. O.Akinade, O. O.Owolabi, H. A.Alaka, H. A. and Pasha, M. (2016), "Big Data in the construction industry: A review of present status, opportunities, and future trends". Advanced engineering informatics, Vol. 30 No. 3. pp. 500521.

Brundu, F. G.Patti, E.Osello, A.Del Giudice, M.Rapetti, N.Krylovskiy, A.Jahn, M.Verda, V.Guelpa, E. and Rietto, L. (2016), "IoT software infrastructure for energy management and simulation in smart cities". IEEE Transactions on Industrial Informatics, Vol. 13 No. 2. pp. 832-840. https://doi.org/10.1109/TII.2016.2627479

Butler, L. and Visser, M. S. (2006), "Extending citation analysis to non-source items". Scientometrics, Vol. 66 No. 2. pp. 327-343. 10.1007/s11192-006-0024-1

Caneppele, S. and Aebi, M. F. (2019), "Crime drop or police recording flop? On the relationship between the decrease of offline crime and the increase of online and hybrid crimes". Policing: 
A Journal of Policy and Practice, Vol. 13 No. 1. pp. 66-79. DOI:

https://doi.org/10.1007/s11192-006-0024-1 Carmona, A. M.Chaparro, A. I.Velásquez,

R.Botero-Valencia, J.Castano-Londono, L.Marquez-Viloria, D. and Mesa, A. M. 2019.

Instrumentation and Data Collection Methodology to Enhance Productivity in Construction

Sites Using Embedded Systems and IoT Technologies. Advances in Informatics and Computing in Civil and Construction Engineering. Springer. DOI:

https://doi.org/10.1007/978-3-030-00220-6_76. ISBN: 978-3-030-00219-0

Chamberlain, D., Edwards, D.J., Lai, J. and Thwala, W.D. (2019), "Mega event management of formula one grand prix: an analysis of literature", Facilities. Vol.37, No. 13/14, pp. 11661184. DOI: https://doi.org/10.1108/F-07-2018-0085

Chiang, Y.-H.Tao, L. and Wong, F. K. (2015), "Causal relationship between construction activities, employment and GDP: The case of Hong Kong". Habitat international, Vol. 46. pp. 1-12. DOI: https://doi.org/10.1016/j.habitatint.2014.10.016

Cobo, M. J.López-Herrera, A. G.Herrera-Viedma, E. and Herrera, F. (2011), "Science mapping software tools: Review, analysis, and cooperative study among tools". Journal of the American Society for Information Science and Technology, Vol. 62 No. 7. pp. 1382-1402.

Čolaković, A. and Hadžialić, M. (2018), "Internet of Things (IoT): A review of enabling technologies, challenges, and open research issues". Computer Networks, Vol. 144. pp. 17-39. https://doi.org/10.1016/j.comnet.2018.07.017

Craveiro, F.Duarte, J. P.Bartolo, H. and Bartolo, P. J. (2019), “Additive manufacturing as an enabling technology for digital construction: A perspective on Construction 4.0". Automation in Construction, Vol. 103. pp. 251-267. https://doi.org/10.1016/j.autcon.2019.03.011

Dallasega, P. (2018), "Industry 4.0 Fostering Construction Supply Chain Management: Lessons Learned From Engineer-to-Order Suppliers". IEEE Engineering Management Review, Vol. 46 No. 3. pp. 49-55. DOI: https://doi.org/10.1109/EMR.2018.2861389

Darko, A.Chan, A. P. C.Adabre, M. A.Edwards, D. J.Hosseini, M. R. and Ameyaw, E. E. (2020), "Artificial intelligence in the AEC industry: Scientometric analysis and visualization of research activities". Automation in Construction, Vol. 112. pp. 103081. https://doi.org/10.1016/j.autcon.2020.103081

Dave, B.Buda, A.Nurminen, A. and Främling, K. (2018), "A framework for integrating BIM and IoT through open standards". Automation in Construction, Vol. 95. pp. 35-45. https://doi.org/10.1016/j.autcon.2018.07.022

Dewan, S. and Singh, L. (2020), "Use of blockchain in designing smart city". Smart and Sustainable Built Environment. 10.1108/sasbe-06-2019-0078

Dixon, C., Edwards, D.J., Lai, H.K., Garcia-Mateo, M., Thwala, W.D., and Shelbourne, M. (2020), "An investigation into the erroneous access and egress behaviours of building users and their impact upon building performance", Facilities. DOI: https://doi.org/10.1108/F-05-2019-0053

Dwivedi, A. D.Srivastava, G.Dhar, S. and Singh, R. (2019), "A decentralized privacy-preserving healthcare blockchain for IoT”. Sensors, Vol. 19 No. 2. pp. 326. DOI: https://doi.org/10.3390/s19020326

Eastman, C. M. a.Lee, G.Sacks, R. and Teicholz, P. M. 2018. BIM handbook : a guide to building information modeling for owners, managers, designers, engineers and contractors, Wiley, Hoboken, New Jersey

Edwards, D. J., Pärn, E. A., Love, P. E. D. and El-Gohary, H. (2017), "Machinery, manumission and economic machinations", Journal of Business Research, Vol. 70, pp. 391-394. DOI:10.1016/j.jbusres.2016.08.012

Edwards, D.Pärn, E.Sing, C. and Thwala, W. D. (2019), "Risk of excavators overturning: determining horizontal centrifugal force when slewing freely suspended loads". Engineering, Construction and Architectural Management, Vol. 26 No. 3. pp. 479-498. DOI:https://doi.org/10.1108/ECAM-03-2018-0125

Farooq, M. U.Waseem, M.Mazhar, S.Khairi, A. and Kamal, T. (2015), "A review on internet of things (IoT)”. International Journal of Computer Applications, Vol. 113 No. 1. pp. 1-7.

Fernando, S.Panuwatwanich, K. and Thorpe, D. (2019), "Analyzing client-led innovation enablers in Australian construction projects". International Journal of Managing Projects in Business. DOI: https://doi.org/10.1108/IJMPB-08-2018-0150. 
Fewings, P. and Henjewele, C. 2019. Construction project management: an integrated approach, Routledge. ISBN-13: 978-0415359061

Gamil, Y.Abdullah, M. A.Abd Rahman, I. and Asad, M. M. (2020), "Internet of things in construction industry revolution 4.0". Journal of Engineering, Design and Technology.

Gammon, T. J. P. S. (2020), "Reflections on Fatal Occupational Injury Rates in the US vs. Importing Countries". Vol. 65 No. 01. pp. 39-46. DOI: https://www.onepetro.org/journal-paper/ASSE20-01-39

Gero, J. S. (1983), "Computer-aided architectural design—past, present and future". Architectural Science Review, Vol. 26 No. 1. pp. 2-5. DOI: https://doi.org/10.1080/00038628.1983.9697249

Ghosh, A., Edwards, D.J., Hossieni, M. Reza., Al-Ameri, R., Abewajy, J. and Thwala, W.D. (2020), "Real-Time Structural Health Monitoring for Concrete Beams: A Cost-Effective 'Industry 4.0' Solution Using Piezo Sensors", International Journal of Building Pathology and Adaptation. Vol. ahead-of-print No. ahead-of-print. https://doi.org/10.1108/IJBPA-12-20190111

Golizadeh, H.Hon, C. K. H.Drogemuller, R. and Reza Hosseini, M. (2018), "Digital engineering potential in addressing causes of construction accidents". Automation in Construction, Vol. 95. pp. 284-295. https://doi.org/10.1016/j.autcon.2018.08.013

Gubbi, J.Buyya, R.Marusic, S. and Palaniswami, M. (2013), "Internet of Things (IoT): A vision, architectural elements, and future directions". Future generation computer systems, Vol. 29 No. 7. pp. 1645-1660.

Guetterman, T. C.Babchuk, W. A.Howell Smith, M. C. and Stevens, J. (2019), “Contemporary approaches to mixed Methods-Grounded theory research: a Field-Based analysis". Journal of Mixed Methods Research, Vol. 13 No. 2. pp. 179-195. DOI: https://doi.org/10.1177/1558689817710877

Haase, J.Alahmad, M.Nishi, H.Ploennigs, J. and Tsang, K. F. The IOT mediated built environment: A brief survey. 2016 IEEE 14th International Conference on Industrial Informatics (INDIN), 19-21 July 2016 2016. 1065-1068. 10.1109/INDIN.2016.7819322

Harden, A. and Thomas, J. 2010. Mixed Methods and Systematic Reviews In: TASHAKKORI, A. \& TEDDLIE, C. (eds.) Sage handbook of mixed methods in social \& behavioral research. 2nd ed, Sage, Thousand Oaks, California. ISBN-13: 978-1412972666

He, Q.Wang, G.Luo, L.Shi, Q.Xie, J. and Meng, X. (2017), "Mapping the managerial areas of Building Information Modeling (BIM) using scientometric analysis". International journal of project management, Vol. 35 No. 4. pp. 670-685. DOI: https://doi.org/10.1016/j.ijproman.2016.08.001

Heiskanen, A. (2017), "The technology of trust: How the Internet of Things and blockchain could usher in a new era of construction productivity". Construction Research and Innovation, Vol. 8 No. 2. pp. 66-70. 10.1080/20450249.2017.1337349

Hosseini, M. R.Chileshe, N.Zuo, J. and Baroudi, B. (2015), “Adopting global virtual engineering teams in AEC Projects". Construction Innovation.

Hosseini, M. R.Maghrebi, M.Akbarnezhad, A.Martek, I. and Arashpour, M. (2018a), "Analysis of citation networks in building information modeling research". Journal of construction engineering and management, Vol. 144 No. 8. pp. 04018064.

Hosseini, M. R.Martek, I.Zavadskas, E. K.Aibinu, A. A.Arashpour, M. and Chileshe, N. (2018b), "Critical evaluation of off-site construction research: A Scientometric analysis". Automation in Construction, Vol. 87. pp. 235-247. DOI: https://doi.org/10.1016/j.autcon.2017.12.002

Jin, R.Gao, S.Cheshmehzangi, A. and Aboagye-Nimo, E. (2018), "A holistic review of off-site construction literature published between 2008 and 2018". Journal of cleaner production. DOI:https://doi.org/10.1016/j.jclepro.2018.08.195

Jin, R.Zou, P. X. W.Piroozfar, P.Wood, H.Yang, Y.Yan, L. and Han, Y. (2019), “A science mapping approach based review of construction safety research". Safety Science, Vol. 113. pp. 285297. https://doi.org/10.1016/j.ssci.2018.12.006

Kaklauskas, A. and Gudauskas, R. 2016. 17 - Intelligent decision-support systems and the Internet of Things for the smart built environment. In: PACHECO-TORGAL, F., RASMUSSEN, E., GRANQVIST, C.-G., IVANOV, V., KAKLAUSKAS, A. \& MAKONIN, S. (eds.) Start-Up Creation. Woodhead Publishing. 
Khajavi, S. H.Motlagh, N. H.Jaribion, A.Werner, L. C. and Holmström, J. (2019), "Digital Twin: Vision, Benefits, Boundaries, and Creation for Buildings". IEEE Access, Vol. 7. pp. 147406147419. 10.1109/ACCESS.2019.2946515

Kobusińska, A.Leung, C.Hsu, C.-H.S, R. and Chang, V. (2018), "Emerging trends, issues and challenges in Internet of Things, Big Data and cloud computing". Future Generation Computer Systems, Vol. 87. pp. 416-419. https://doi.org/10.1016/j.future.2018.05.021

Kumar, S. A.Vealey, T. and Srivastava, H. Security in internet of things: Challenges, solutions and future directions. 2016 49th Hawaii International Conference on System Sciences (HICSS), 2016. IEEE, 5772-5781.

Langmade, L. 2017. Productivity in the Construction Industry Is Declining - Here's How Mobile Can Help. Available from: https://blog.plangrid.com/2017/11/productivity-constructionindustry-declining-heres-mobile-can-help-

infographic/?doing_wp_cron=1565208511.4229009151458740234375 [Accessed November $8,2017$.

Levin, P. H. (1964), "Use of graphs to decide the optimum layout of buildings". The Architects' Journal, Vol. 7. pp. 809-815.

Li, J.Greenwood, D. and Kassem, M. (2019), "Blockchain in the built environment and construction industry: A systematic review, conceptual models and practical use cases". Automation in Construction, Vol. 102. pp. 288-307.

Li, Y. and Liu, C. (2019), "Applications of multirotor drone technologies in construction management". International Journal of Construction Management, Vol. 19 No. 5. pp. 401412.

Loosemore, M. (2015), "Construction innovation: Fifth generation perspective”. Journal of management in engineering, Vol. 31 No. 6. pp. 04015012. DOI: https://doi.org/10.1061/(ASCE)ME.1943-5479.0000368

Louis, J. and Dunston, P. S. (2018), "Integrating IoT into operational workflows for real-time and automated decision-making in repetitive construction operations". Automation in Construction, Vol. 94. pp. 317-327.

Madakam, S. and Uchiya, T. 2019. Industrial Internet of Things (IIoT): Principles, Processes and Protocols. The Internet of Things in the Industrial Sector. Springer. DOI: https://doi.org/10.1007/978-3-030-24892-5_2

Mahon, N. A. and Joyce, C. W. (2015), "A bibliometric analysis of the 50 most cited papers in cleft lip and palate". Journal of plastic surgery and hand surgery, Vol. 49 No. 1. pp. 52-58. DOI: https://doi.org/10.3109/2000656X.2014.951053

Malina, M. A.Nørreklit, H. S. and Selto, F. H. (2011), "Lessons learned: advantages and disadvantages of mixed method research". Qualitative Research in Accounting \& Management, Vol. 8 No. 1. pp. 59-71.

Maskuriy, R.Selamat, A.Maresova, P.Krejcar, O. and David, O. O. (2019), "Industry 4.0 for the construction industry: review of management perspective". Economies, Vol. 7 No. 3. pp. 68.

Melià-Seguí, J. and Vilajosana, X. Ubiquitous moisture sensing in automaker industry based on standard UHF RFID tags. 2019 IEEE International Conference on RFID (RFID), 2019. IEEE, 1-8. DOI: https://doi.org/10.1109/RFID.2019.8719092

Mohamed, I. F.Edwards, D. J.Mateo-Garcia, M.Costin, G. and Thwala, W. D. D. (2019), “An investigation into the construction industry's view on fire prevention in high-rise buildings post Grenfell". International Journal of Building Pathology and Adaptation. DOI: https://doi.org/10.1108/IJBPA-05-2019-0048

Mourtzis, D.Vlachou, E. and Milas, N. (2016), "Industrial Big Data as a result of IoT adoption in manufacturing". Procedia cirp, Vol. 55. pp. 290-295.

Newman, C.Edwards, D. J.Martek, I.Lai, J. and Thwala, W. D. (2020), "Industry 4.0 Deployment in the Construction Industry: A Bibliometric Literature Review and UK-based Case Study". Smart and Sustainable Built Environment.

Nieuwenkamp, R. 2016. The Global Construction Sector Needs a Big Push on Corporate Responsibility. Available from: http://oecdinsights.org/2016/08/22/global-constructionsector-corporate-responsibility/ [Accessed Aug 22, 2016 2019]. 
Niu, Y.Lu, W.Chen, K.Huang, G. G. and Anumba, C. (2015), "Smart construction objects". Journal of Computing in Civil Engineering, Vol. 30 No. 4. pp. 04015070. DOI: https://doi.org/10.1061/(ASCE)CP.1943-5487.0000550

Oesterreich, T. D. and Teuteberg, F. (2016), "Understanding the implications of digitisation and automation in the context of Industry 4.0: A triangulation approach and elements of a research agenda for the construction industry". Computers in Industry, Vol. 83. pp. 121-139. DOI: https://doi.org/10.1016/j.compind.2016.09.006

Oraee, M.Hosseini, M. R.Papadonikolaki, E.Palliyaguru, R. and Arashpour, M. (2017), "Collaboration in BIM-based construction networks: A bibliometric-qualitative literature review". International Journal of Project Management, Vol. 35 No. 7. pp. 1288-1301.

Papageorgiou, G. and Demetriou, G. (2019), "Investigating learning and diffusion strategies for sustainable mobility". Smart and Sustainable Built Environment. Pärn, E. A. and Edwards, D. J. (2017), "Conceptualising the FINDD API plug-in: a study of BIM-FM integration", Automation in Construction, Vol. 80, pp. 11-21. DOI: https://doi.org/10.1016/j.autcon.2017.03.015

Pärn, E. A. and Edwards, D. J. (2019), "Cyber threats confronting the digital built environment: Common data environment vulnerabilities and block chain deterrence", Engineering, Construction and Architectural Management, Vol. 26 No. 2, pp. 245-266. DOI: https://doi.org/10.1108/ECAM-03-2018-0101

Perera, C.Zaslavsky, A.Christen, P. and Georgakopoulos, D. 2014. Context aware computing for the internet of things: A survey. IEEE communications surveys tutorials.

Ramasundara, Y.Johnson, A. and Baumeister, D. 2018. Australia's IoT Opportunity: Driving Future Growth An ACS Report. ACS. Available via: https://www.acs.org.au/insightsandpublications/reports-publications/iot-opportunity.html [Accessed: 23 ${ }^{\text {rd }}$ April, 2020]

Reportlinker. 2019. Construction Global Market Report [Online]. PR Newswire Association LLC. Available: https://www.prnewswire.com/news-releases/the-global-construction-market-wasestimated-to-be-around-17140-billion-as-of-2017-300713756.html [Accessed 24 April 2020].

Riaz, Z., Edwards, D. J. and Thorpe, A. (2006), "SightSafety: A hybrid information and communication technology system for reducing vehicle/pedestrian collisions", Automation in Construction, Vol. 15, No. 6, pp. 719 - 728. DOI:10.1016/j.autcon.2005.09.004

Riaz, Z., Pärn, E. A., Edwards, D. J., Arslan, M., Shen, C. and Peña-Mora, F. (2017), "BIM and sensor-based data management system for construction safety monitoring", Journal of Engineering Design and Technology, Vol. 15, No. 6, pp. 738-753. DOI: https://doi.org/10.1108/JEDT-03-2017-0017

Roberts, C.Edwards, D. J.Hosseini, M. R.Mateo-Garcia, M. and Owusu-Manu, D.-G. (2019), "Postoccupancy evaluation: a review of literature". Engineering, Construction and Architectural Management. https://doi.org/10.1108/ECAM-09-2018-0390

Roberts, C. J.Pärn, E. A.Edwards, D. J. and Aigbavboa, C. (2018), "Digitalising asset management: concomitant benefits and persistent challenges". International Journal of Building Pathology and Adaptation, Vol. 36 No. 2. pp. 152-173. DOI:10.1108/IJBPA-09-2017-0036

Santos, R.Costa, A. A. and Grilo, A. (2017), "Bibliometric analysis and review of Building Information Modelling literature published between 2005 and 2015". Automation in Construction, Vol. 80. pp. 118-136. DOI: https://doi.org/10.1016/j.autcon.2017.03.005

Sawhney, A.Riley, M. and Irizarry, J. 2020. Construction 4. 0 : An Innovation Platform for the Built Environment, Routledge, Milton, United Kingdom. ISBN: 9780367027308

Shen, G.Bu, S.Anumba, C. J.Wong, A. K. and Liang, X. (2015), "Literature review of green retrofit design for commercial buildings with BIM implication". Smart and Sustainable Built Environment.

Slaughter, E. S. (2000), "Implementation of construction innovations". Building research information Management, Vol. 28 No. 1. pp. 2-17. DOI: https://doi.org/10.1080/096132100369055

Souder, J. J. and Clark, W. E. (1963), “Computer technology: A new tool for planning”. AIA Journal, Vol. 10. pp. 97-106. 
Souri, A.Hussien, A.Hoseyninezhad, M. and Norouzi, M. "A systematic review of IoT communication strategies for an efficient smart environment". Transactions on Emerging Telecommunications Technologies, Vol. n/a No. n/a. pp. e3736. 10.1002/ett.3736

Sriram Changali, Azam Mohammad and Nieuwland, M. v. 2013. The Construction Productivity Imperative. McKinsey \& Company. Available via: https://www.mckinsey.com/industries/capital-projects-and-infrastructure/our-insights/theconstruction-productivity-imperative [Accessed: 23 ${ }^{\text {rd }}$ April, 2020].

Sun, J. Design and implementation of IOT-based logistics management system. 2012 IEEE Symposium on Electrical \& Electronics Engineering (EEESYM), 24-27 June 2012 2012. 603606. 10.1109/EEESym.2012.6258730

Sutrisna, M.Cooper-Cooke, B.Goulding, J. and Ezcan, V. (2019), "Investigating the cost of offsite construction housing in Western Australia". International Journal of Housing Markets Analysis, Vol. 12 No. 1. pp. 5-24. DOI: https://doi.org/10.1108/IJHMA-05-2018-0029

Tan, T.Chen, K.Xue, F. and Lu, W. (2019), "Barriers to Building Information Modeling (BIM) implementation in China's prefabricated construction: An interpretive structural modeling (ISM) approach". Journal of Cleaner Production, Vol. 219. pp. 949-959. DOI: https://doi.org/10.1016/j.jclepro.2019.02.141

Tang, S.Shelden, D. R.Eastman, C. M.Pishdad-Bozorgi, P. and Gao, X. (2019), “A review of building information modeling (BIM) and the internet of things (IoT) devices integration: Present status and future trends". Automation in Construction, Vol. 101. pp. 127-139. https://doi.org/10.1016/j.autcon.2019.01.020

Turner, A. (2015), "Generation Z: Technology and social interest". The Journal of Individual Psychology, Vol. 71 No. 2. pp. 103-113. DOI: https://doi.org/10.1353/jip.2015.0021

Veras, P. R.Suresh, S. and Renukappa, S. The Adoption of Big Data Concepts for Sustainable Practices Implementation in the Construction Industry. 2018 IEEE/ACM International Conference on Utility and Cloud Computing Companion (UCC Companion), 17-20 Dec. 2018 2018. 349-352. 10.1109/UCC-Companion.2018.00079

Waters, L. and McAlpine, R. 2016. Construction as a career of choice for young people. London, UK: Chartered Institute of Building. Available via: https://www.ciob.org/sites/default/files/View\%20Liz\%27s\%20full\%20report\%20here.pdf [Accessed: 23 ${ }^{\text {rd }}$ April, 2020].

Wing, C. K. (1997), "The ranking of construction management journals". Construction Management and Economics, Vol. 15 No. 4. pp. 387-398. 10.1080/014461997372953

Woodhead, R.Stephenson, P. and Morrey, D. (2018), "Digital construction: From point solutions to IoT ecosystem". Automation in Construction, Vol. 93. pp. 35-46. 10.1016/j.autcon.2018.05.004

Xu, G.Li, M.Chen, C.-H. and Wei, Y. (2018), "Cloud asset-enabled integrated IoT platform for lean prefabricated construction". Automation in Construction, Vol. 93. pp. 123-134.

Yi, W. and Chan, A. P. (2014), "Critical review of labor productivity research in construction journals". Journal of management in engineering, Vol. 30 No. 2. pp. 214-225.

Zhong, R. Y.Xu, X.Klotz, E. and Newman, S. T. (2017), "Intelligent Manufacturing in the Context of Industry 4.0: A Review”. Engineering, Vol. 3 No. 5. pp. 616-630. https://doi.org/10.1016/J.ENG.2017.05.015 
Figure 1 - Research Design (tri-pronged mixed methods systematic review)

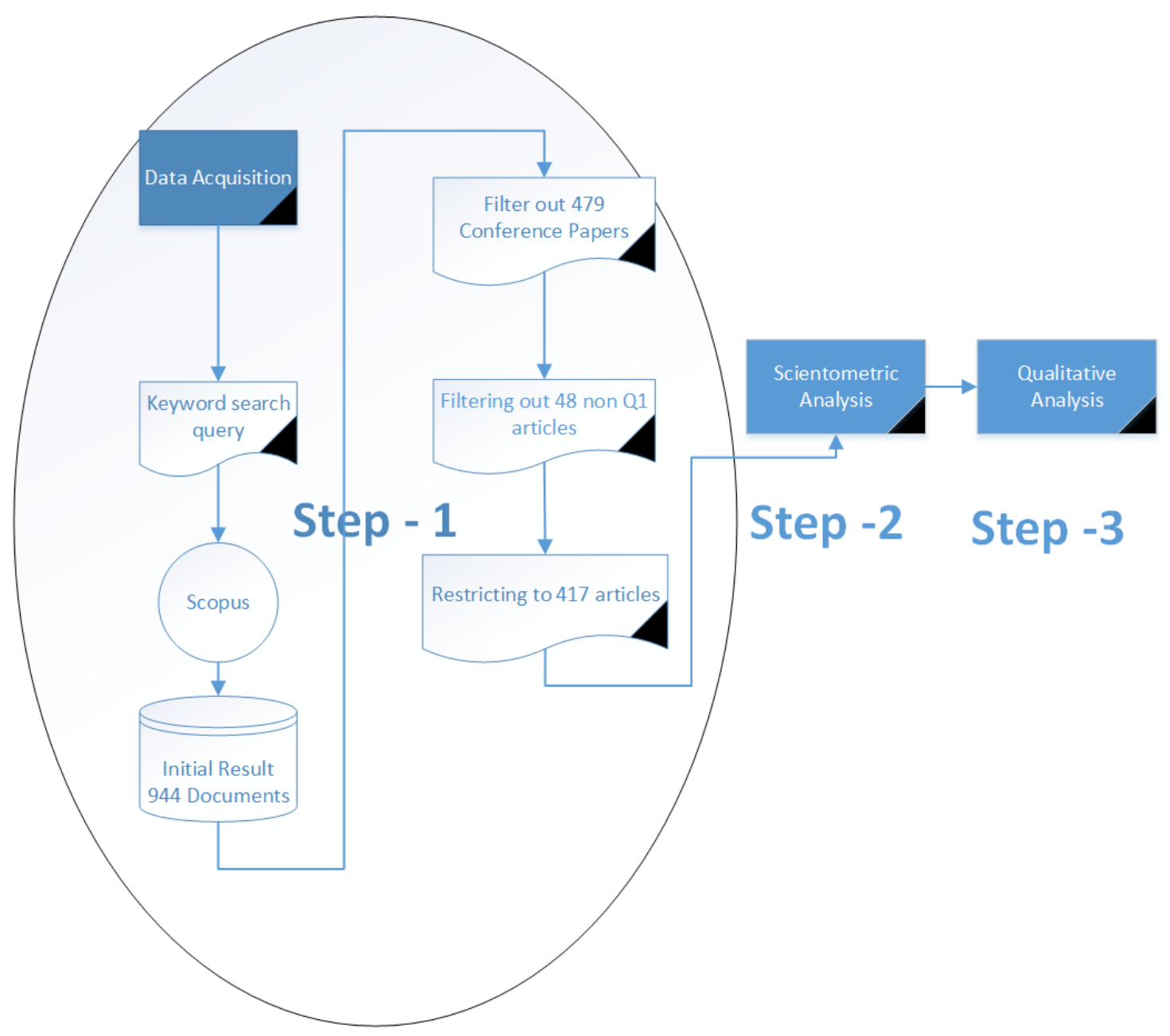


Figure 2 - Breakup of journal outlets facilitating research in IoT in construction industry (Scopus) (1988-2020)

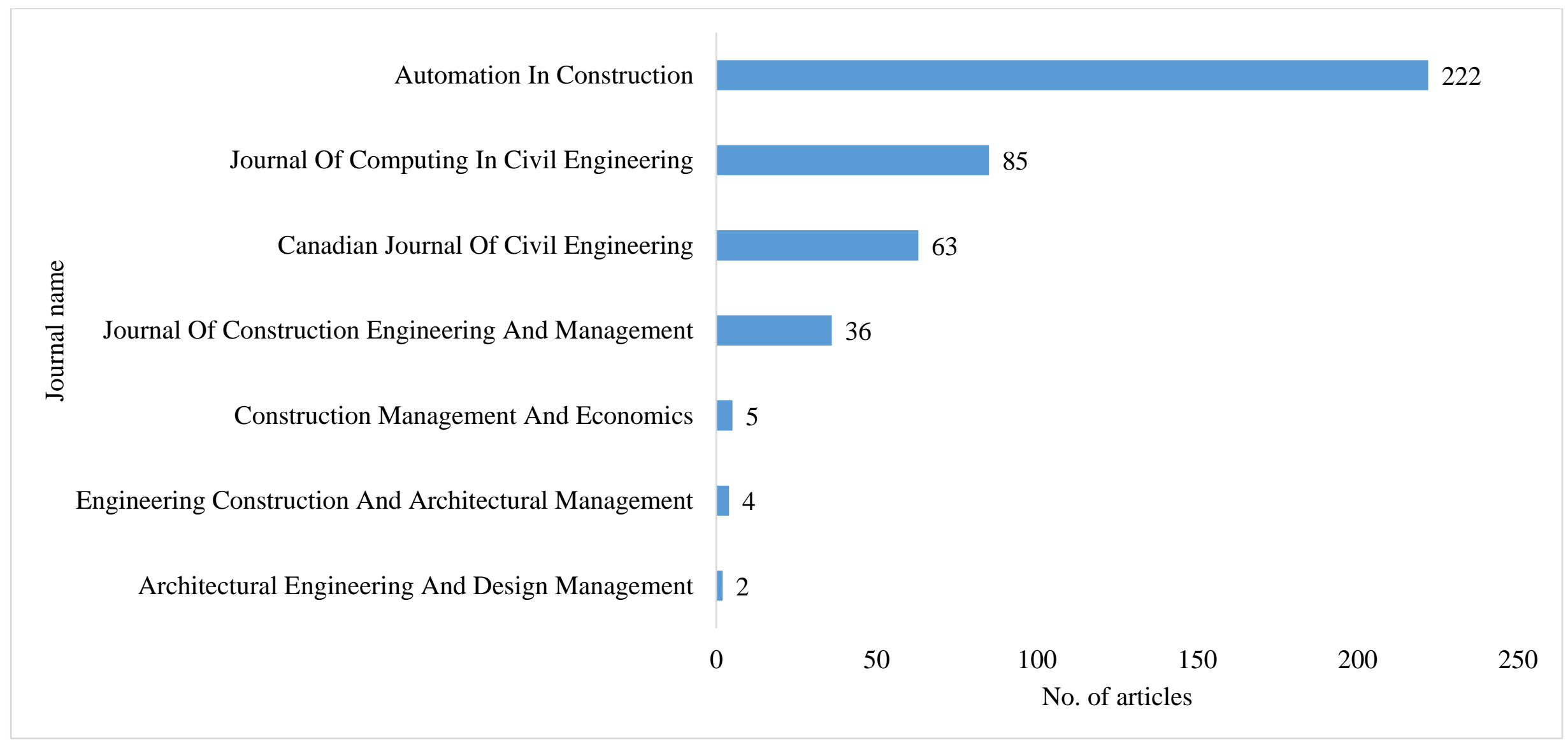


Figure 3 - Wave of research in IoT related articles in construction industry (Scopus) (1988-2020)

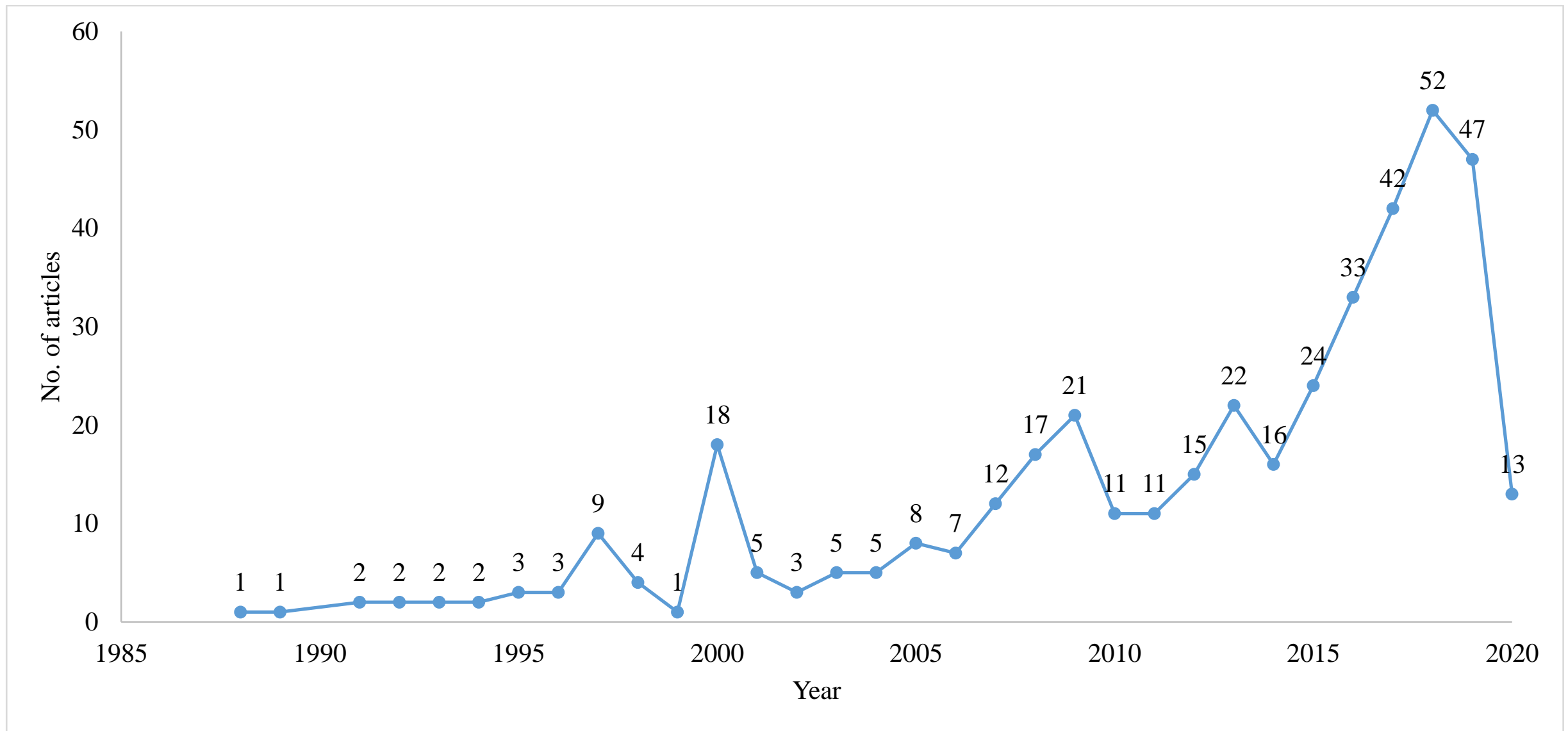


Figure 4 - Subject area in research in IoT in construction industry (Scopus) (1988-2020)

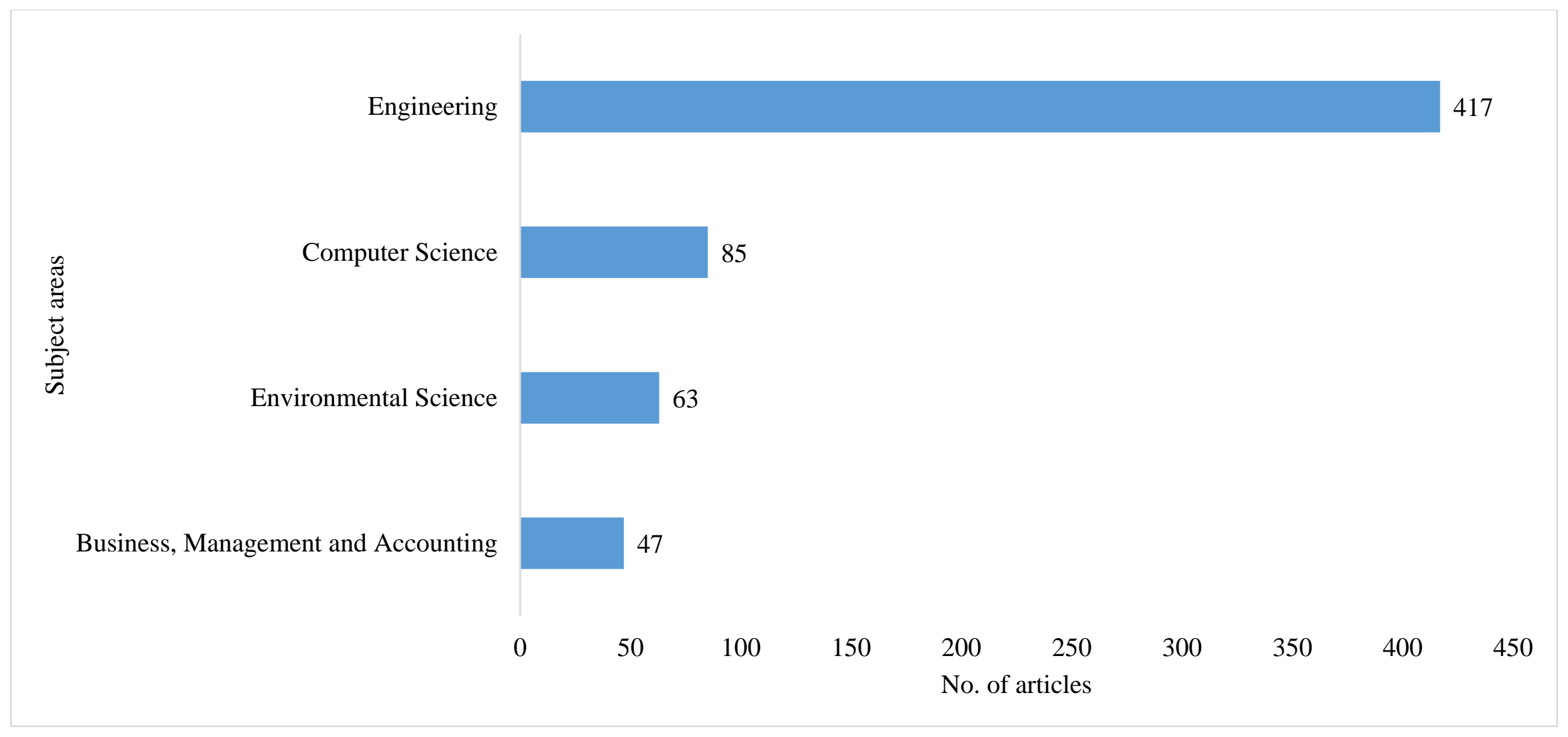


Figure 5 - Top 10 institutions in research outputs in IoT in construction industry (1988-2020)(Scopus)

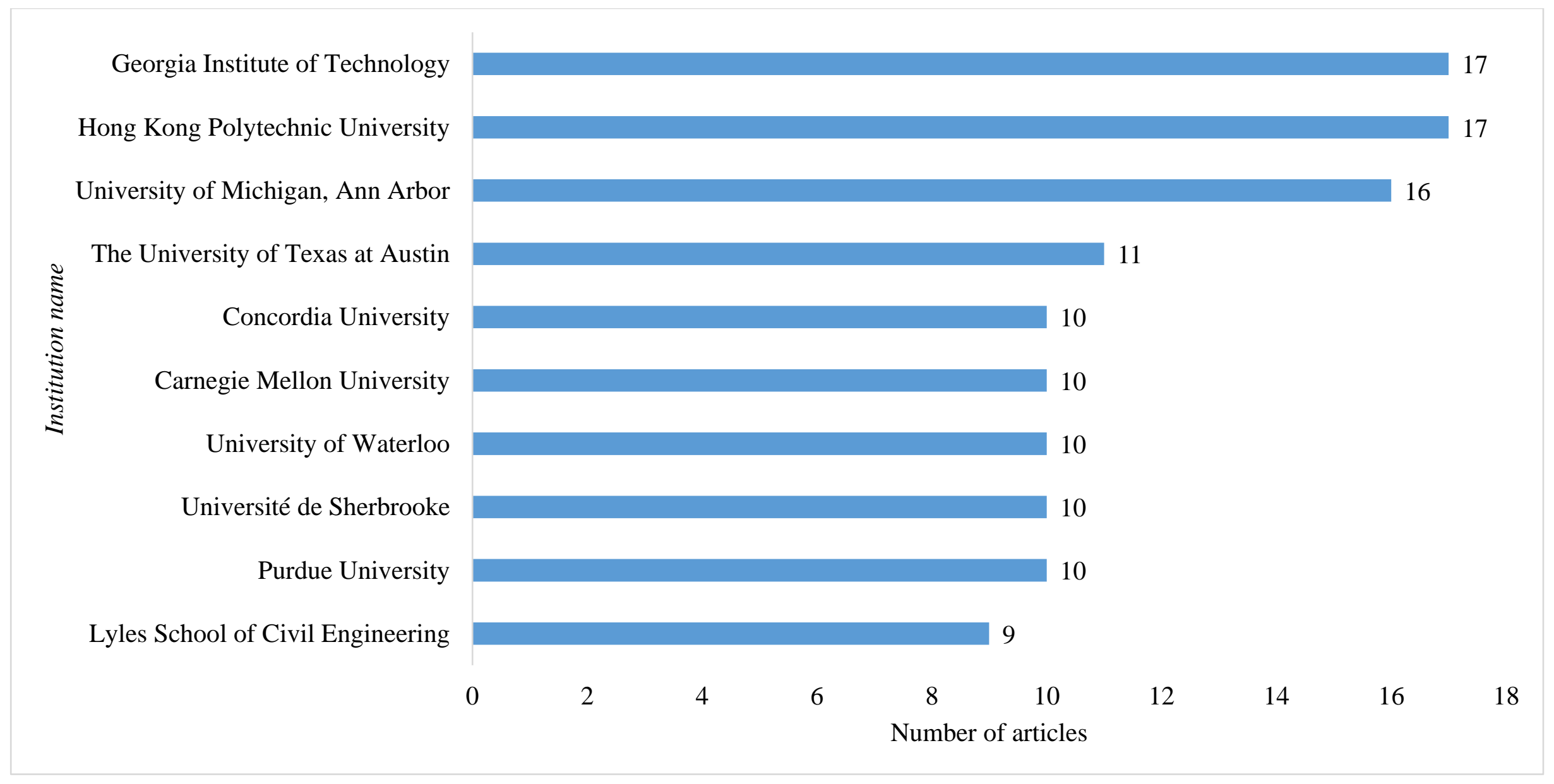


Figure 6 - Top 10 research funding bodies in Industry 4.0 in construction industry (Scopus) (1988-2020)

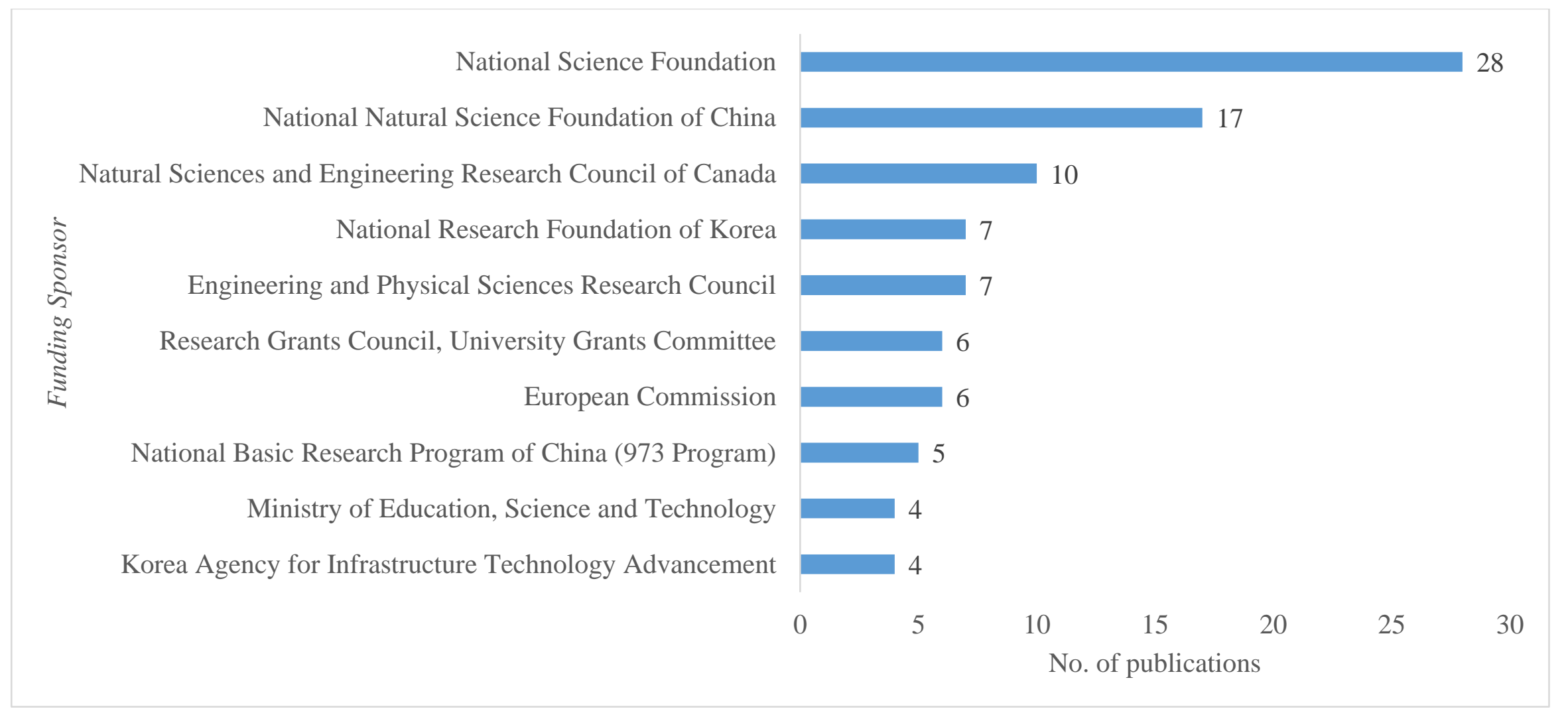


Figure 7 - Text Map Vosviewer Analysis Industry 4.0 in construction industry papers (Scopus)(1983-2019)

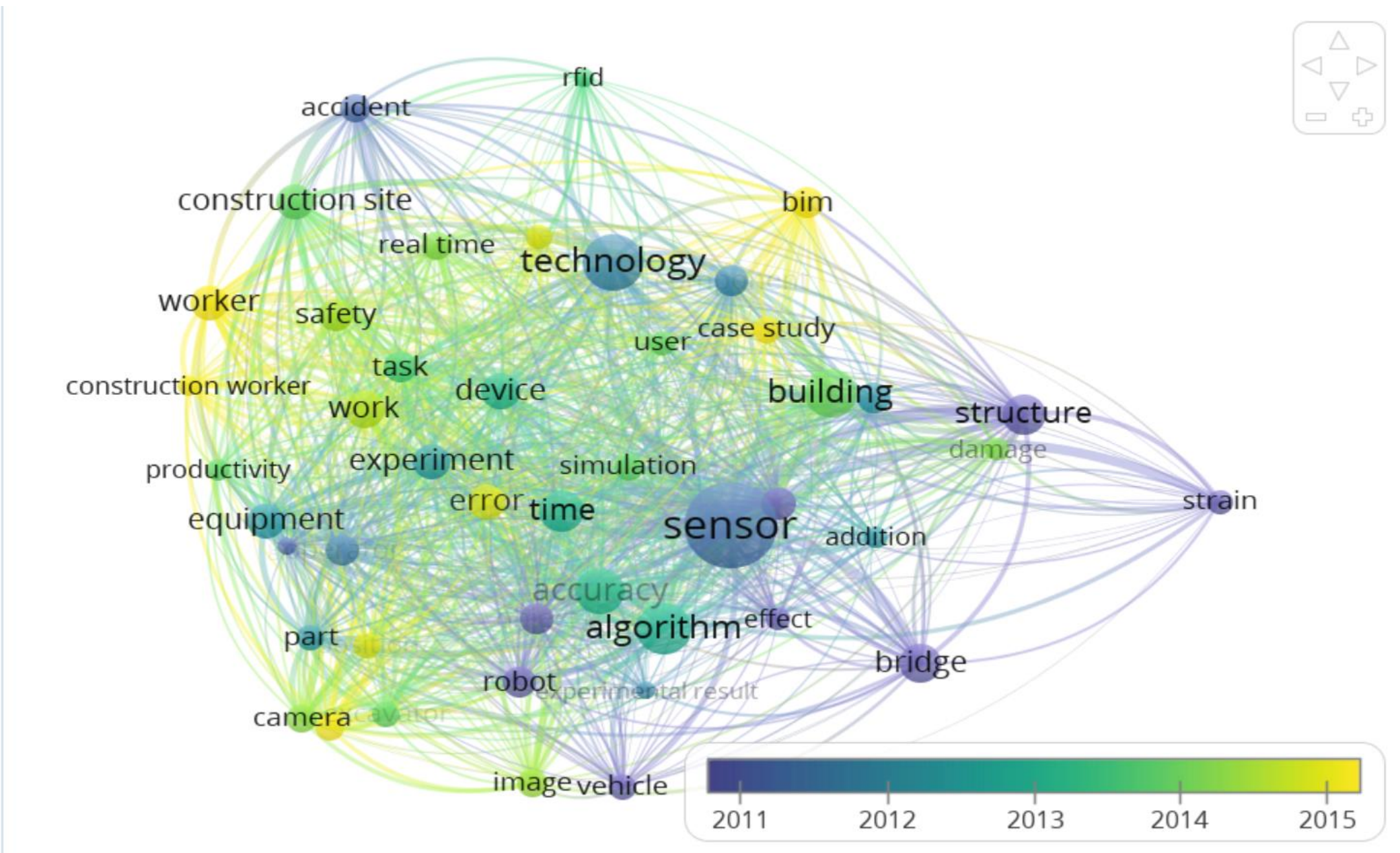


Figure 8 - Author collaboration networks IoT in construction industry papers (Scopus)(1988-2020)

smith i.f.c.

brilakis i.

kimh.

akinci b.

choi b.

jebelli $h$.

lees.

muftia.a.

kamat v.r.seo j.

lih.

\section{(ij.}

moselhi o.

teizer j.

cheng $\mathrm{t}$. jang w.-s.

bernold l.e.

haas c.t.

benmokrane $b$.

chen $\mathrm{j}$.

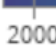

2000 2005

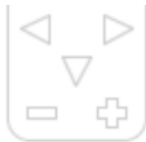

becerik-gerber $b$. 
Figure 9 - Organisation collaboration map in IoT in construction industry review papers- Larger circles denote higher citation count

(Scopus)(1988-2020)

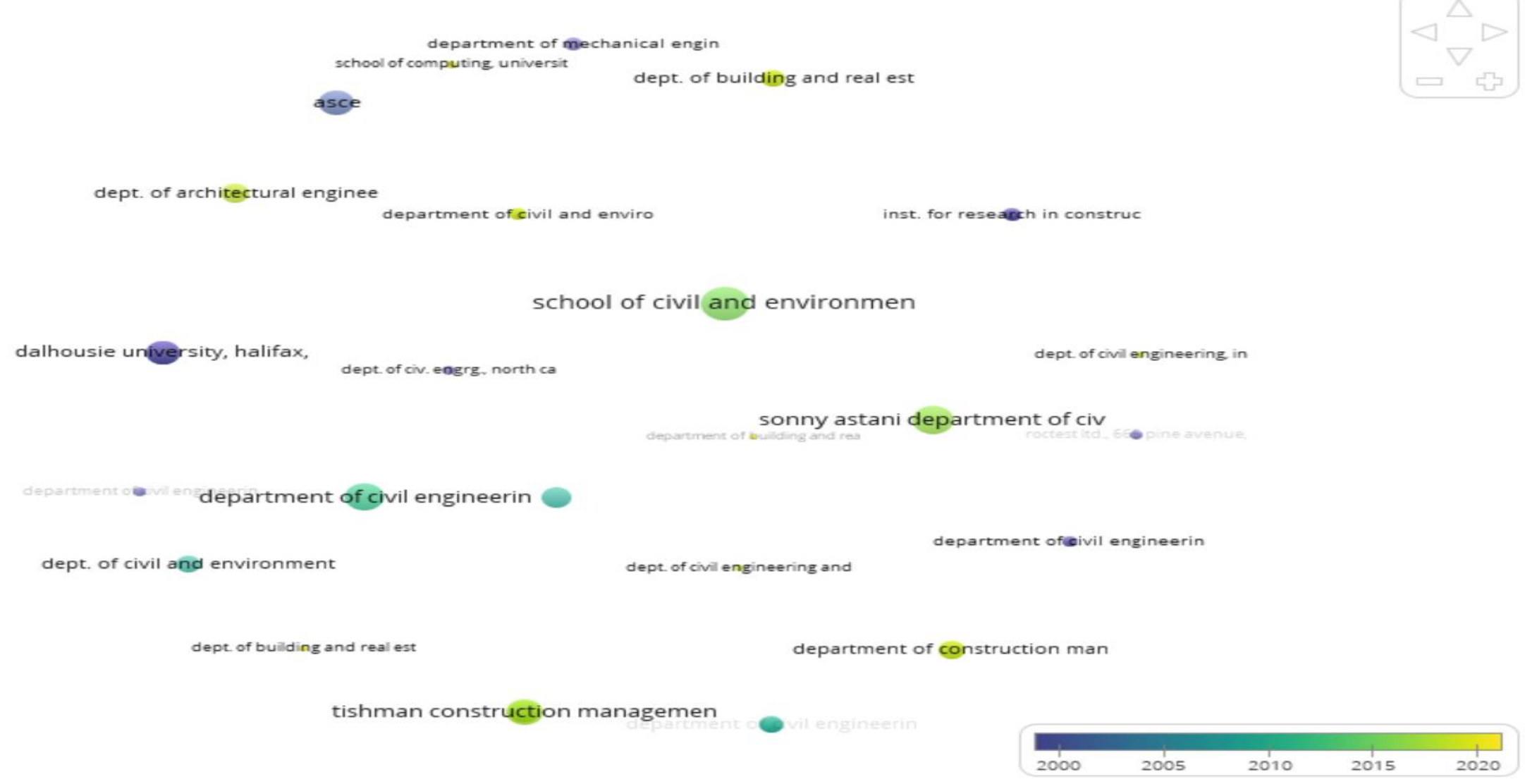


Figure 10 - Country collaboration map of IoT research in construction industry - Larger circles denote higher citation count (Scopus)(1988-

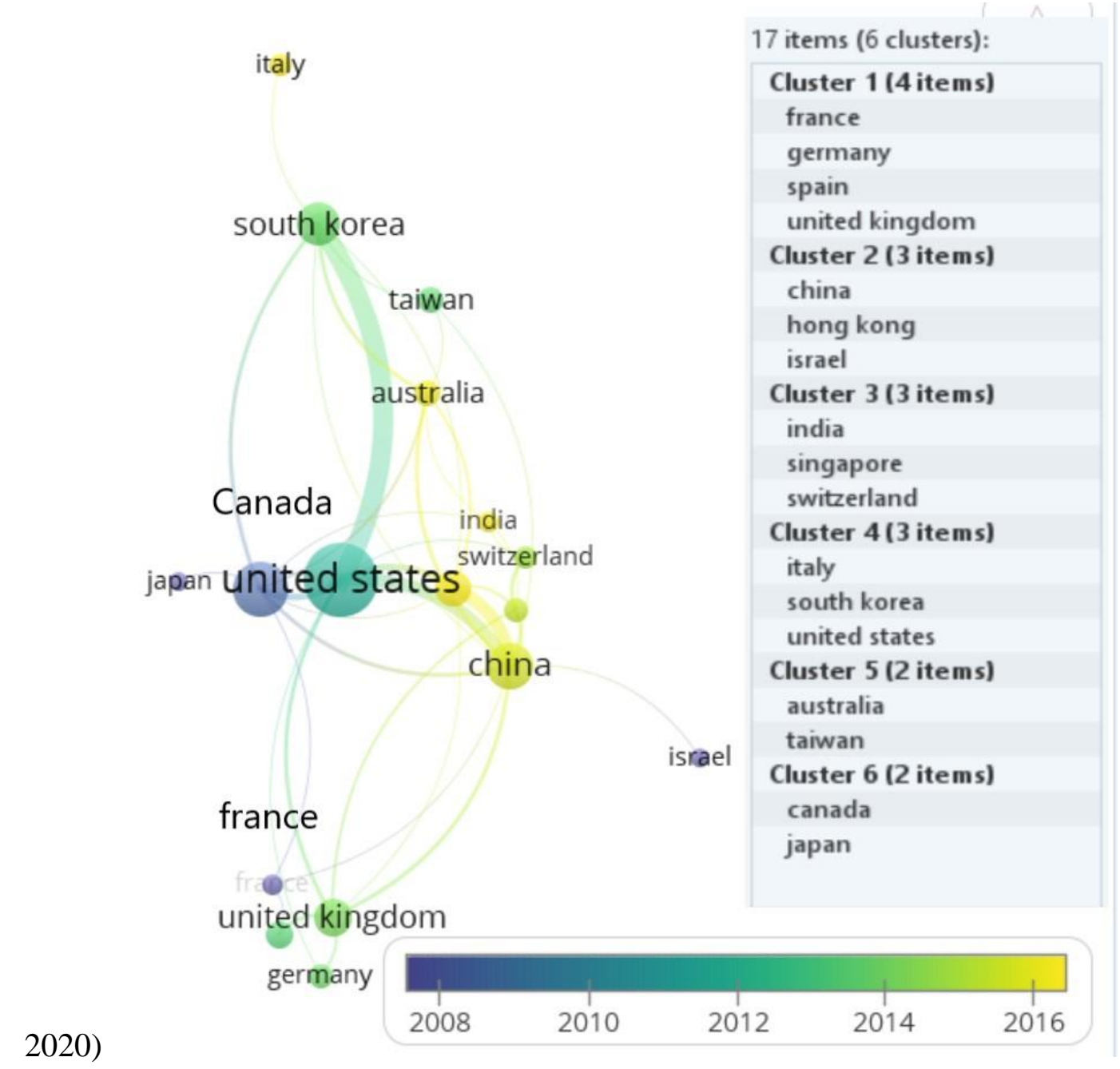


Appendix-1

Research Clusters from Text Map of Scopus database

\begin{tabular}{|c|c|c|c|c|}
\hline \multicolumn{5}{|c|}{ Cluster 1 (14 items)[structural health monitoring ] } \\
\hline addition & BIM & bridge & building & case study \\
\hline component & damage & effect & sensor & strain \\
\hline strategy & structure & type & user & \\
\hline \multicolumn{5}{|c|}{ Cluster 2 (12 items)[construction safety] } \\
\hline accident & challenge & $\begin{array}{l}\text { construction } \\
\text { site }\end{array}$ & $\begin{array}{l}\text { construction } \\
\text { worker }\end{array}$ & device \\
\hline productivity & real-time & RFID & safety & task \\
\hline work & worker & & & \\
\hline \multicolumn{5}{|c|}{ Cluster 3 (10 items)[optimisation and simulation] } \\
\hline accuracy & algorithm & error & experiment & $\begin{array}{l}\text { experimental } \\
\text { result }\end{array}$ \\
\hline gps & object & position & robot & simulation \\
\hline \multicolumn{5}{|c|}{ Cluster 4 (9 items) [image processing] } \\
\hline camera & equipment & excavator & image & operator \\
\hline part & time & vehicle & vision & \\
\hline
\end{tabular}




\section{Organisation Top 10 Clusters}

\begin{tabular}{|c|c|c|c|}
\hline $\begin{array}{l}\text { Institute for Research in Construction, National } \\
\text { Research Council of Canada, Ottawa, Canada. }\end{array}$ & $\begin{array}{l}\text { Institut de Recherche D'Hydro-Quebec, } \\
\text { Quebec, Canada. }\end{array}$ & $\begin{array}{l}\text { ISIS Canada, Department of civil } \\
\text { engineering, University of } \\
\text { Sherbrooke, Canada. }\end{array}$ & $\begin{array}{l}\text { LES } \\
\text { Laboratoires } \\
\text { Outaouais } \\
\text { Inc., Canada }\end{array}$ \\
\hline \multicolumn{4}{|l|}{ Cluster 2 [3 items] Canadian Universities cluster 2} \\
\hline Dalhousie University, Halifax, Canada. & $\begin{array}{l}\text { Department of Electrical and Computer } \\
\text { Engineering, University of Toronto, Canada. }\end{array}$ & $\begin{array}{l}\text { Institute for aerospace studies, } \\
\text { University of Toronto, Canada. }\end{array}$ & \\
\hline \multicolumn{4}{|c|}{ Cluster 3 [3 items] Hong Kong - USA University collaboration } \\
\hline $\begin{array}{l}\text { Department of Building and Real Estate, Hong } \\
\text { Kong Polytechnic University, Hong Kong. }\end{array}$ & $\begin{array}{l}\text { Mitsubishi Electric Research Laboratories, } \\
\text { Massachusetts, United States. }\end{array}$ & $\begin{array}{l}\text { Tishman construction } \\
\text { management program, } \\
\text { Department. of civil and } \\
\text { environmental engineering, } \\
\text { University of Michigan, United } \\
\text { States. }\end{array}$ & \\
\hline \multicolumn{4}{|l|}{ Cluster 5 [2 items] } \\
\hline $\begin{array}{l}\text { Department of Civil and Environmental } \\
\text { Engineering, University of Michigan, } 2350\end{array}$ & $\begin{array}{l}\text { Taubman College of Architecture And } \\
\text { Urban Planning, University of Michigan, }\end{array}$ & & \\
\hline
\end{tabular}




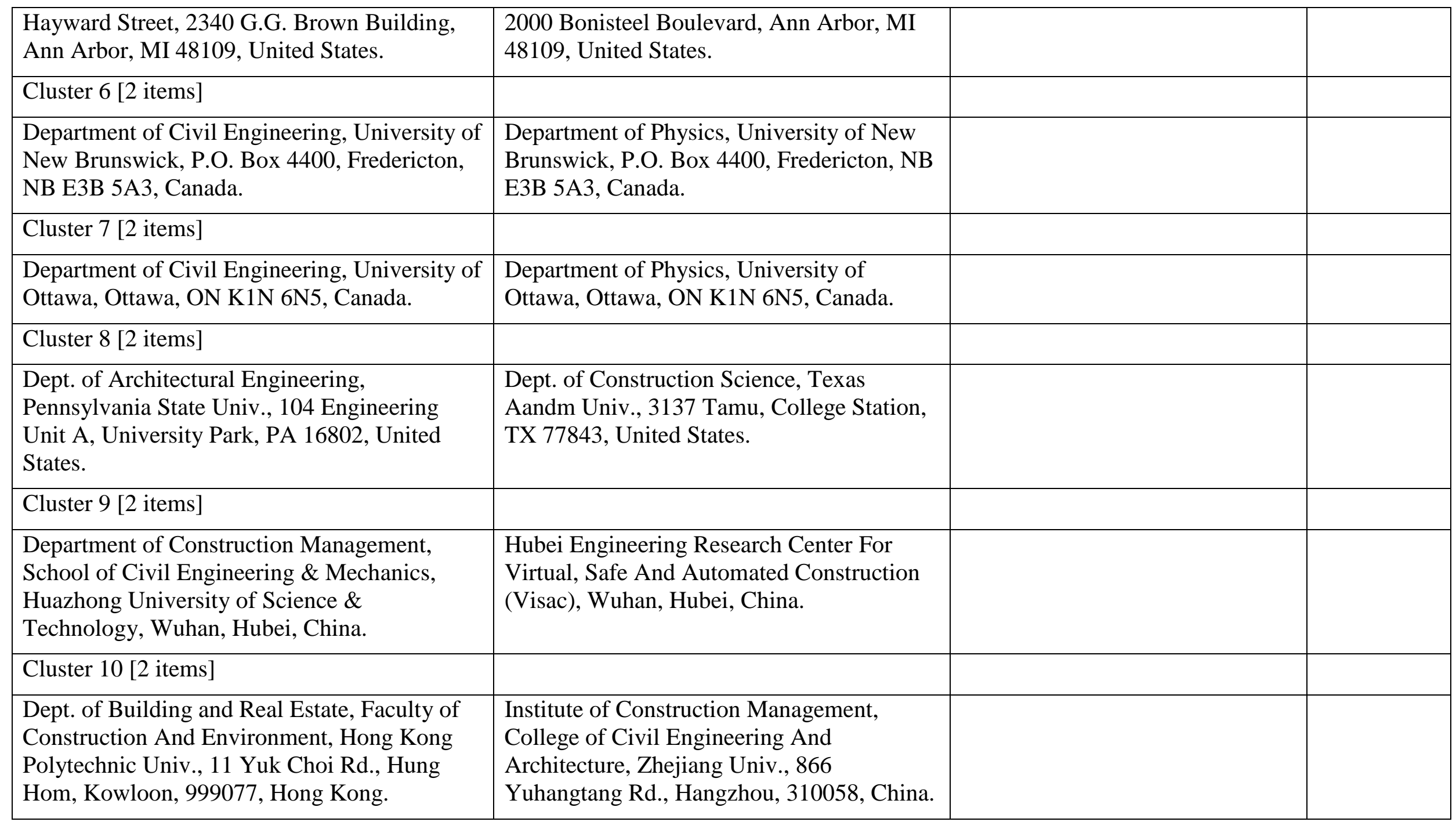


